\title{
Research progress on human genes involved in the pathogenesis of glaucoma (Review)
}

\author{
HONG-WEI WANG ${ }^{1}$, PENG SUN ${ }^{2}$, YAO CHEN ${ }^{1}$, LI-PING JIANG ${ }^{3}$, HUI-PING WU ${ }^{4}$, WEN ZHANG ${ }^{5}$ and FENG GAO ${ }^{6}$ \\ ${ }^{1}$ Department of Ophthalmology, Jingjiang People's Hospital, Jingjiang, Jiangsu 214500; ${ }^{2}$ Department of Ophthalmology, \\ Longgang District People's Hospital, Shenzhen, Guangdong 518172; ${ }^{3}$ Department of Ophthalmology, \\ The First Affiliated Hospital of Qiqihar Medical University, Qiqihar, Heilongjiang 161041; \\ ${ }^{4}$ Department of The Scientific Research, Jingjiang People's Hospital, Jingjiang, Jiangsu 214500; \\ ${ }^{5}$ Medical School, Nantong University, Nantong, Jiangsu 226001; ${ }^{6}$ Department of Hospital Administration, \\ Jingjiang People's Hospital, Jingjiang, Jiangsu 214500, P.R. China
}

Received November 10, 2017; Accepted April 12, 2018

DOI: $10.3892 / \mathrm{mmr} .2018 .9071$

\begin{abstract}
Glaucoma is the leading cause of irreversible blindness globally. It is known that the incidence of glaucoma is closely associated with inheritance. A large number of studies have suggested that genetic factors are involved in the occurrence and development of glaucoma, and even affect the drug sensitivity and prognosis of glaucoma. In the present review, 22 loci of glaucoma are presented, including the relevant genes (myocilin, interleukin 20 receptor subunit $\mathrm{B}$, optineurin, ankyrin repeat- and SOCS box-containing protein 10 , WD repeat-containing protein 36, EGF-containing fibulin-like extracellular matrix protein 1 , neurotrophin 4, TANK-binding kinase 1 , cytochrome P450 subfamily I polypeptide 1, latent transforming growth factor $\beta$ binding protein 2 and TEK tyrosine kinase endothelial) and 74 other genes (including toll-like receptor 4 , sine oculis homeobox Drosophila homolog of 1, doublecortin-like kinase 1, RE repeats-encoding gene, retinitis pigmentosa GTPase regulator-interacting protein, lysyl oxidase-like protein 1 , heat-shock $70-\mathrm{kDa}$ protein $1 \mathrm{~A}$, baculoviral IAP repeat-containing protein $6,5,10$-methylenetetrahydrofolate reductase and nitric oxide synthase 3 and nanophthalmos 1) that are more closely associated with glaucoma. The pathogenesis of these glaucoma-associated genes, glaucomatous genetics and genetic approaches, as well as glaucomatous risk factors, including increasing age, glaucoma family history, high myopia, diabetes, ocular trauma, smoking, intraocular pressure increase and/or fluctuation were also discussed.
\end{abstract}

Correspondence to: Dr Feng Gao, Department of Hospital Administration, Jingjiang People's Hospital, 28 Jingjiang Zhongzhou Road, Jingjiang, Jiangsu 214500, P.R. China

E-mail: wangyutingwangxin@163.com

Key words: gene, human glaucoma, pathogenesis, risk factor

\section{Contents}

1. Introduction

2. Genetics of glaucoma

3. Genetic approaches for glaucoma study

4. Pathogenic genes associated with glaucoma

5. MYOC in the GLC1A locus

6. Pathogenic genes in the GLC1B-GLC1Q loci

7. Pathogenic genes in the GLC3A-GLC3E loci

8. Potential pathogenic mechanism and recent advances in treatment

9. Conclusion and prospects

\section{Introduction}

Glaucoma, a neurodegenerative eye disease, may lead to damage to the optic nerve and consequent vision loss, and is the leading cause of irreversible blindness globally (1). Vision loss results from damage to the optic nerve, which is caused by increased intraocular pressure (IOP) in glaucoma. If untreated, once vision loss from glaucoma has occurred, it is life long. There are an estimated 57.5 million people worldwide with glaucoma (2); for every 1,000 people, approximately eight are affected with glaucoma. It has been reported recently that there will be 79.6 million people with glaucoma by 2020 (3) and an expected 111.8 million glaucoma cases by 2040 (4). Glaucoma has numerous subtypes; however, the different types have a number of common clinical manifestations, including nausea, mid-dilated pupils, serious eye pain, redness and blurred vision (5). Glaucoma has a number of classifications, according to anatomy, etiology, onset age and pathogenesis, and the clinical classifications (6) are presented in Fig. 1.

Besides genetics, there are numerous other risk factors for glaucoma, including increasing age (7-9), estrogen (10), frailty (11), myopia (12), diabetes (13-17), high myopia (18), hyperopia (19), hypertension (20), vasospasm (13), low ocular perfusion pressure (21), family history of glaucoma (7), sex (22), race (23), migraine (24), pigmentary dispersion syndrome (25), pseudoexfoliation syndrome (PEX) (7,9), oral microbiome (26), 
butanoate metabolism (27), unstable oxygen supply (28), infection (29,30), hematopoietic cell lineage (27), the p38-mitogen activated protein kinase pathway (31), retinitis pigmentosa (32), mitochondrial dysfunction (33), obstructive sleep apnea syndrome (34), basal transcription factors (27), calcium channel medication, $\alpha$-blocker medication (7), treatment for systemic hypertension or Raynaud's disease (35), adrenergic agents (36), $\gamma$-aminobutyric acid and acetyl-coenzyme A metabolism (27), sulfa-based drug (36), corticosteroids (37), smoking (17), lysine degradation (27), IOP fluctuation (38), IOP increase (39) and caffeine (40). Of those risk factors for glaucoma mentioned, increased IOP is the strongest risk factor in the majority of subtypes of glaucoma (41); however, its pathogenesis remains unclear. Increased IOP may subsequently lead to posterior displacement and thinning of the lamina cribrosa (LC), which causes axonal damage and disrupted axonal transport to and from the lateral geniculate nucleus (LGN). Disruption of axonal transport interrupts retrograde delivery of nutrients from relay neurons of the LGN to retinal ganglion cells (RGCs) (42), possibly leading to the death of RGCs.

In addition to the afore-mentioned pathogenic factors for glaucoma, heredity additionally serves an important role in the pathogenesis of glaucoma. A previous study suggested that glaucoma maybe inherited from one generation to the next (43), indicating that specific types of glaucoma may have a genetic basis. Furthermore, familial clustering and twin studies demonstrate that specific types of glaucoma arise from heredity $(44,45)$. The present review focuses on the current understanding and newest breakthroughs in pathogenic genes for glaucoma with the purpose of providing a comprehensive analysis of how reported gene mutations involved in glaucoma lead to the clinical phenotypes expressed in glaucoma. An overview of glaucoma-associated genes is presented.

\section{Genetics of glaucoma}

It is well known that there is a genetic basis for glaucoma in specific populations due to sex, ethnicity and positive family history predisposition to glaucoma. There has been strong evidence suggesting that glaucoma is markedly affected by genetic factors and is a complex, multi-factorial disease (46). Glaucoma has numerous types, of which the two most common are primary open-angle glaucoma (POAG) and primary angle-closure glaucoma (PACG) (47). POAG is associated with high heritability and complex genetic factors. POAG is responsible for $74 \%$ of all glaucoma cases, of which $47 \%$ of POAG cases are of Asian descent and 24\% are European (1). In contrast to Asian and European descent, the prevalence of severe and rapid POAG progression is increased in Hispanic and African-Caribbean populations $(48,49)$. A previous study additionally suggested that American Caucasians have a lower prevalence of severe and rapid POAG compared with African Americans, who have the highest severe and rapid POAG prevalence (5.2\% at 60 years and $12.2 \%$ at 80 years) (50). The increase in POAG prevalence per decade of age is highest among Hispanic and Caucasian populations, with the lowest in East and South Asian populations (50). There has been strong evidence that the POAG incidence in populations of African descent is two to five times higher compared with those of European descent $(50,51)$. All the data suggests that POAG is affected via ancestral factors associated with genetics. Furthermore, certain articles indicate that men are more susceptible to POAG compared with women in Australia (52) and the Netherlands (53). Abu-Amero et al (50) demonstrated that a positive family history is a risk factor for POAG. A previous study demonstrated that the prevalence among individuals with a positive family history of POAG is five to 10 times greater compared with individuals without a positive family history (54).

For PACG, a positive family history is one of the principal risk factors. There is a lot of evidence to support the hypothesis. From previous studies it is known that there is high prevalence among siblings of patients affected with PACG (55), and that the risk of having PACG is increased by 3.7 times in Greenland Eskimos (56,57), 3.5 times in Eskimos (58), and six times in the Chinese (59) for siblings with a positive family history. Furthermore, high IOP $(60,61)$ and the depth of the anterior chamber $(56,57)$ are associated with genetic factors involved in the pathogenesis of PACG. The association between the depth of the anterior chamber and PACG reveals that a predisposition of morphological features to PACG is additionally heritable. It is recognized that high IOP and the size of the anterior chamber are markedly affected in PACG. Besides genetic risk factors, PACG is additionally associated with sex. There is evidence that the sex ratio of PACG prevalence is $\sim 3.25$ female to 1 male (62).

\section{Genetic approaches for glaucoma study}

Research on glaucoma inheritance has benefited from the development of genetic approaches to identify loci that are involved in a specific glaucomatous phenotype or mutations that account for glaucoma. Traditional linkage analysis based on one or more families with multiple members affected with glaucoma have been widely used to establish the linkage of different phenotypes of glaucoma to particular loci [GLC1A to GLC1N (63), GLC1P (63), GLC3A Online Mendelian Inheritance in Man (OMIM) no. 231300], GLC3B (OMIM no. 600975) and has been less frequently applied to glaucomatous gene mutations, except myocilin (MYOC) $(64,65)$, optineurin (OPTN) $(65,66)$, glutathione S-transferase mu-1 (65), WD repeat-containing protein 36 (WDR36) (65,67-69), cytochrome P450 subfamily I polypeptide 1 (CYP1B1) (65), neurotrophin 4 (NTF4) (70), ankyrin repeat- and SOCS box-containing protein 10 (ASB10) (71) and TANK-binding kinase 1 (TBK1) (63). The aforementioned studies demonstrated that this approach is useful to identify glaucomatous loci. However, linkage analysis is largely limited by its reliance on prior knowledge of disease pathophysiology. This traditional candidate gene approach appears to have been powerless to examine an unclear pathophysiology of complex diseases, such as glaucoma $(72,73)$.

Glaucoma is a complex disease, which may be a polygenic disease rather than a monogenic disease. Glaucoma-causing genes have small variations, including single nucleotide polymorphisms (SNPs), and larger variations, including copy number variations (CNVs). Furthermore, the pathogenic levels of these variations differ, from highly to medium to weakly pathogenic, possibly pathogenic, or even protective. Therefore, traditional linkage analysis has not been applicable to study 


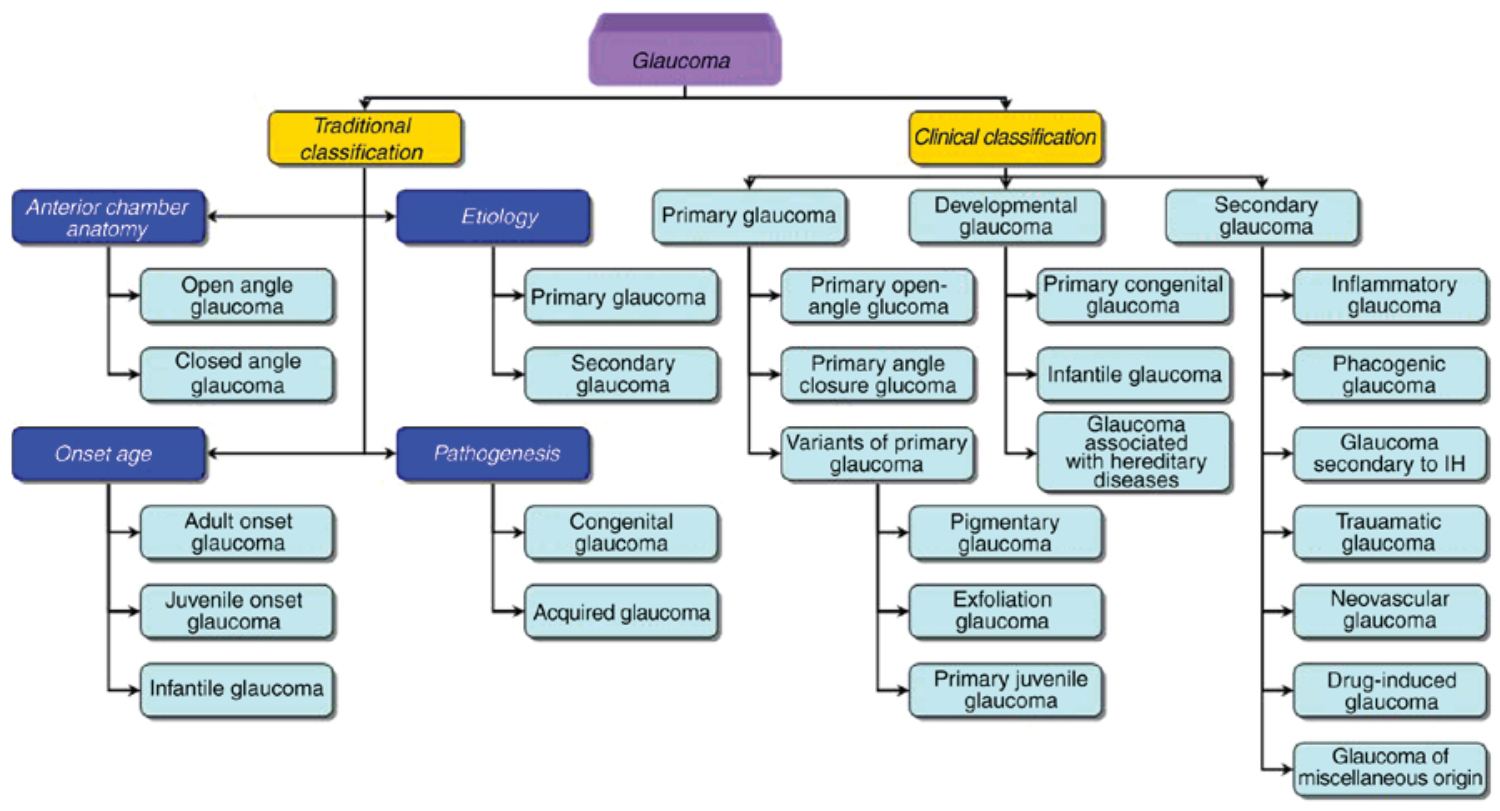

Figure 1. General classifications of glaucoma. IH, intraocular hemorrhage.

these variations in glaucoma, which is more complex and with unknown pathophysiology (72). A suggested alternative to linkage analysis, genome-wide association studies (GWAS), based on SNPs arrays (73), was proposed. GWAS, additionally known as whole genome association studies, is a genome-wide approach that compares the genetic profile of SNPs throughout the genome, among affected cases and unaffected controls to see if any genomic regions are associated with a certain trait or disease (73). In the examination of the glaucomatous pathology, the most common approach of GWAS to glaucoma is the case-control setup; one control group and the other case group affected with glaucoma. GWAS primarily focuses on the associations between SNPs and traits of glaucoma. There is strong evidence that GWAS is more powerful than linkage analysis in identifying causal variations in genes of weak effect, which may account for the development of glaucoma $(73,74)$.

It was thought that SNPs were the most prevalent genetic variations. However, recently, certain studies revealed CNVs area principal source of variations (73) that may be pathogenic in POAG (75). CNVs manifest primarily as submicroscopic deletions and duplications. Numerous CNVs in POAG have been reported. It is worth mentioning that $\mathrm{CNVs}$ contain more nucleotide content compared with SNPs per genome, and that suggests the importance of CNVs in the evolution and diversity of genes (76).

\section{Pathogenic genes associated with glaucoma}

Pathogenic genes located in the GLC1A-GLC1Q and GLC3A-GLC3E loci. To date, 22 loci of glaucoma (Table I) have been identified and designated as GLC1A-Q and GLC3A-E. POAG is linked to 17 loci; GLC1A, 1C, 1E-H, $1 \mathrm{O}-\mathrm{P}$, for which the responsible genes are MYOC, interleukin 20 receptor subunit $\beta$ (IL20RB), OPTN, ASB10, WDR36, EGF containing fibulin-like extracellular matrix protein 1 (EFEMP1), NTF4 and TBK1, respectively; and
GLC1B, 1D, 1I-N, and 1Q, for which the responsible genes remain unidentified. There are five loci linking to primary congenital glaucoma (PCG), GLC3A and 3D-E, for which the responsible genes are $\mathrm{CYP} 1 \mathrm{~B} 1$, latent transforming growth factor- $\beta$-binding-protein 2 (LTBP2) and TEK tyrosine kinase endothelial (TEK), respectively; the responsible genes of GLC3B-C remain unidentified. GLC1A-Q, except GLC1A, $1 \mathrm{~J}, 1 \mathrm{~K}, 1 \mathrm{M}$ and $1 \mathrm{~N}$, which contribute only to juvenile open angle glaucoma (JOAG), contribute to adult-onset POAG. All of GLC3A-E have been implicated in PCG. Glaucoma-causing mutations may be classified into two groups. One is autosomal dominant, including POAG-causing genes (MYOC, IL20RB, OPTN, EFEMP1 and TBK1) and a PCG-causing gene (TEK). The other is autosomal recessive, including a PCG-causing gene (CYP1B1). Of the 22 loci, GLC1A (MYOC) and GLC3A (CYP1B1) are the most important for glaucoma; they have correspondingly been the most investigated in research.

Only four pathogenic genes, MYOC $(64,65)$, NTF4 $(65,70)$, OPTN $(65,77)$ and WDR36 $(65,78)$, have been definitively linked to POAG. Furthermore, it was reported that mutations in OPTN, MYOC or WDR36 account for $4 \%$ of all glaucoma (79). The link between ASB10, IL20RB and EFEMP1, and POAG, is less certain. TBK1 is controversial, since GLC1P covers three other genes, n-acetylglucosamine-6-sulfatase, ras association domain family protein 3 and exportin-t (80); however, TBK1 has been suggested to be the most possible glaucoma-causing gene for GLC1P (80).

Only one pathogenic gene for PCG, CYP1B1 (6), has been clearly identified in the locus GLC3A. Numerous genes have been observed in 1p36 that contain GLC3B, however, none have been demonstrated to be associated with PCG (6). To date, it remains to be investigated whether LTBP2 is associated with the GLC3C or GLC3D loci. LTBP2 is $\sim 1.3 \mathrm{Mb}$ proximal to GLC3C (82), thus there is a hypothesis that LTBP2 may be the GLC3C gene; however, the possibility that it may be an adjacent gene associated with PCG may not be ruled out. Another study suggested that GLC3D is distal to GLC3C 


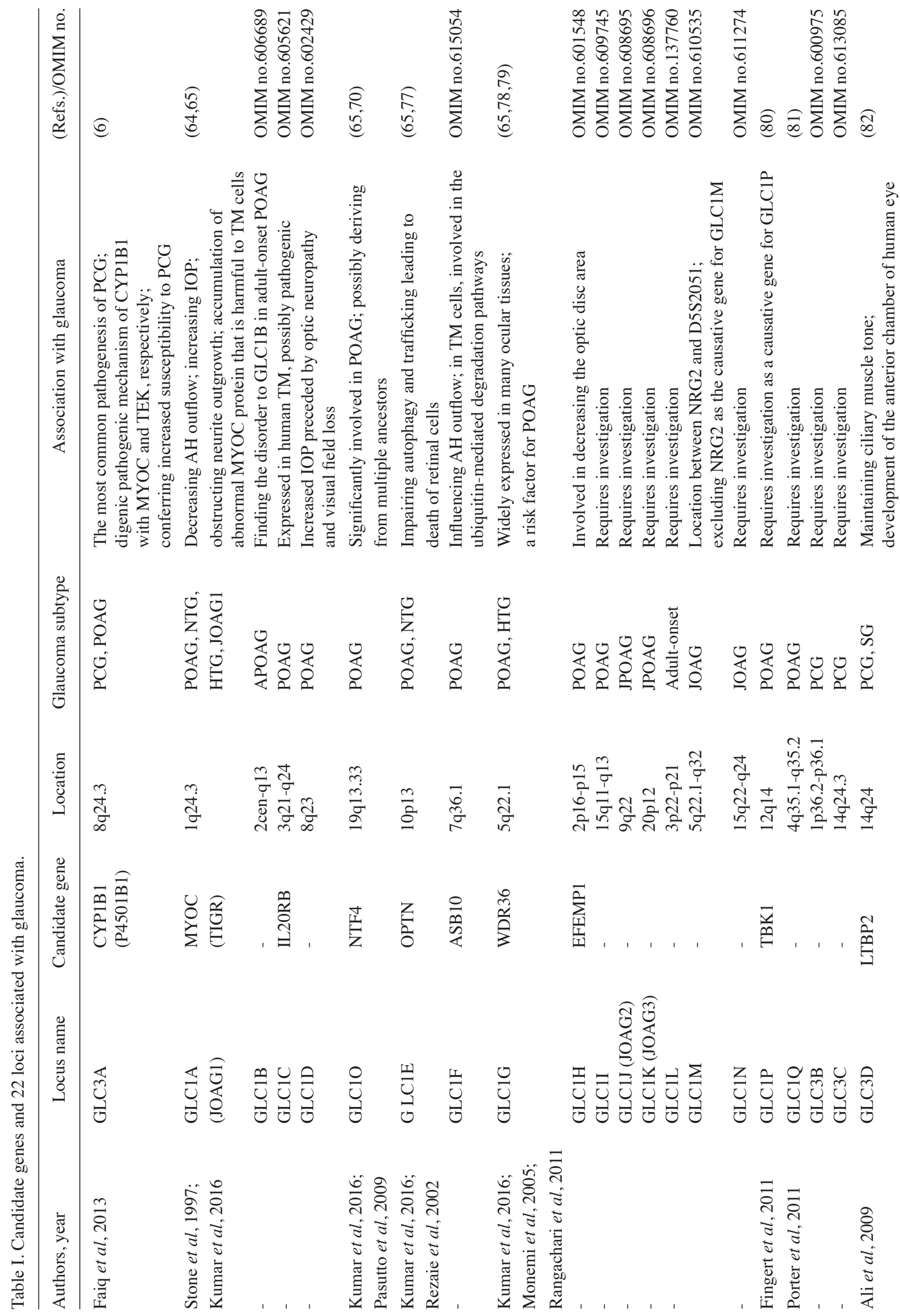


without overlapping (83). Furthermore, there is evidence that LTBP2 is a candidate for GLC3D (82); therefore, in the present review LTBP2 is presented as the GLC3D gene. There is strong evidence (OMIM) that mutations of TEK may result in GLC3E, and the locus of TEK is GLC3E.

Other genes associated with glaucoma. To the best of the authors' knowledge, besides the 22 loci of glaucoma mentioned, there are 74 genes that are more closely associated with glaucoma presented in Table II. Of those 74, 48 (64\%) are associated with POAG, followed by PACG (16\%), PCG (4\%) and pseudoexfoliation glaucoma (PEXG; 4\%). Toll-like receptor 4, sine oculis homeobox Drosophila homolog of 1, doublecortin-like kinase $1, \mathrm{RE}$ repeats-encoding gene, retinitis pigmentosa GTPase regulator-interacting protein, lysyl oxidase-like protein 1 (LOXL1), heat-shock $70-\mathrm{kD}$ protein $1 \mathrm{~A}$ (HSP70-1), baculoviral IAP repeat-containing protein 6, 5,10-methylenetetrahydrofolate reductase (MTHFR) and nitric oxide synthase 3 (ENOS) are human genes involved in more than one phenotype of glaucoma. Nanophthalmos 1 is identified to be the only human gene known to cause PACG (140). For other genes (ATP-binding cassette subfamily $\mathrm{C}$ member 5 , SPARC-related modular calcium-binding protein 2, matrix metalloproteinase 9, membrane-type frizzled-related protein, hepatocyte growth factor, HSP70-1, pleckstrin homology domain-containing protein family A member 7, collagen type XI $\alpha-1$, MTHFR and ENOS) identified to be associated with PACG in Table II, it remains unclear whether they are pathogenic genes for PACG; however, they may be a risk factor for the development of PACG. Among genes associated with PEXG and PEX, the majority of research has been conducted on LOXL1 to determine whether it is pathogenic and how it contributes to the two diseases. PEX, characterized by the accumulation of protein fibers in the eyes, may have a genetic basis. The accumulation of protein obstructs aqueous humor (AH) outflow, and that results in PEXG. Previously, two studies $(111,141)$ have confirmed that LOXL1 is significantly associated with PEXG and PEX. A decrease in LOXL1 expressionmay cause degenerative tissue alterations in LC, and consequently results in patients with PEX being more vulnerable to optic nerve damage caused by pressure (141), a risk factor for PEXG development.

\section{MYOC in the GLC1A locus}

To date, the majority of research efforts have been on MYOC among all the glaucoma-causing genes. There is a consensus that 2-4\% of POAG cases harbor MYOC mutations (142) and MYOC mutations have been reported to be the most frequent in POAG. In the present review, the research findings on MYOC are detailed and summarized. In 1993, Sheffield et al (143) discovered the first genetic locus, GLC1A, for POAG, and in 1997, a glaucoma-causing gene, MYOC, was identified by Stone et al (64). MYOC is a gene associated with POAG, JOAG, normal tension glaucoma (NTG), high-tension glaucoma (HTG) and steroid-induced glaucoma (144). In 1997, the location of MYOC was linked to chromosome 1q23-q24 by Kubota et al (145), and there was a report on fine mapping to chromosome 1q24.3-q25.2 (146). In 1998, cells treated with steroids secreted the same MYOC protein, which was termed 


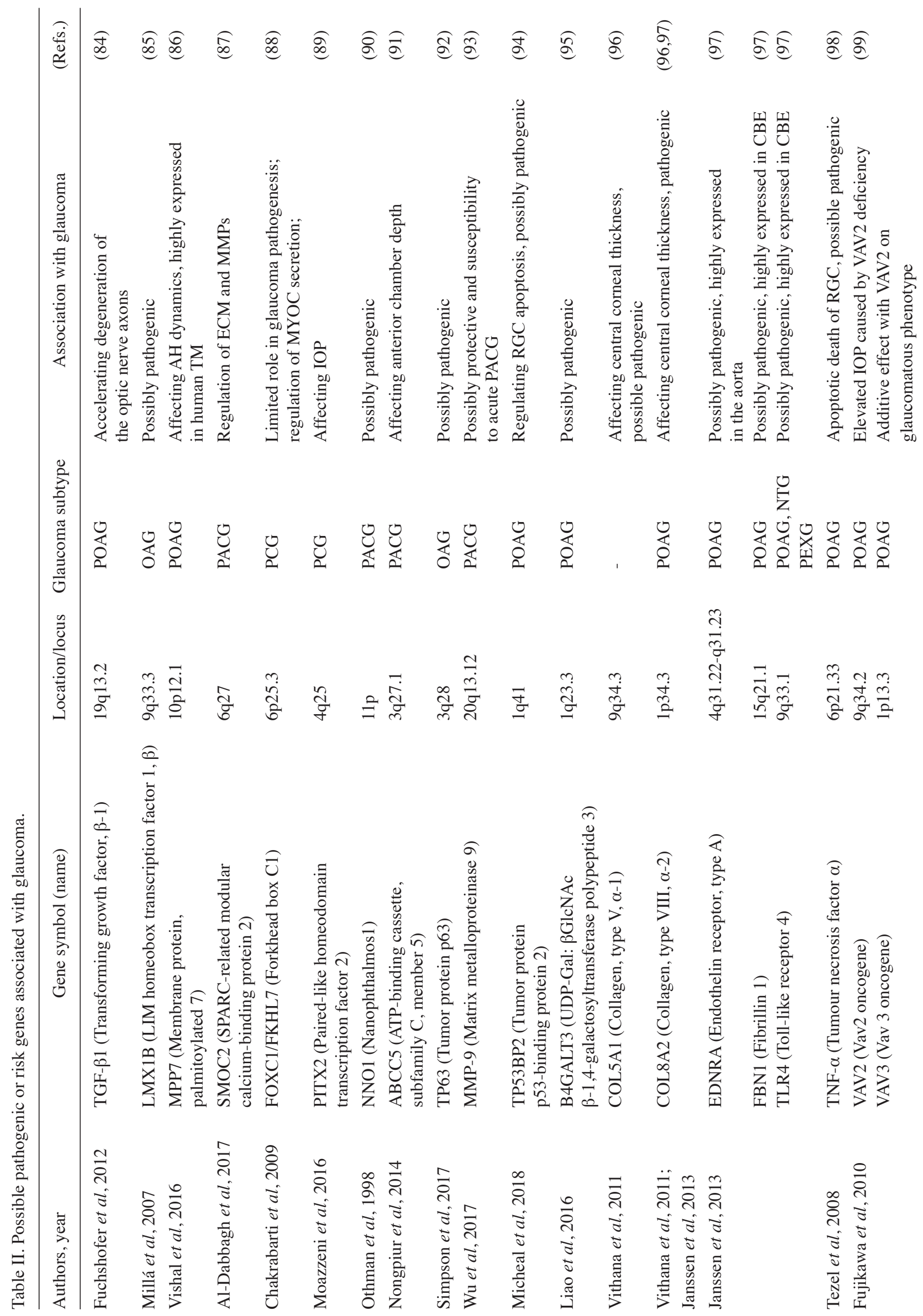




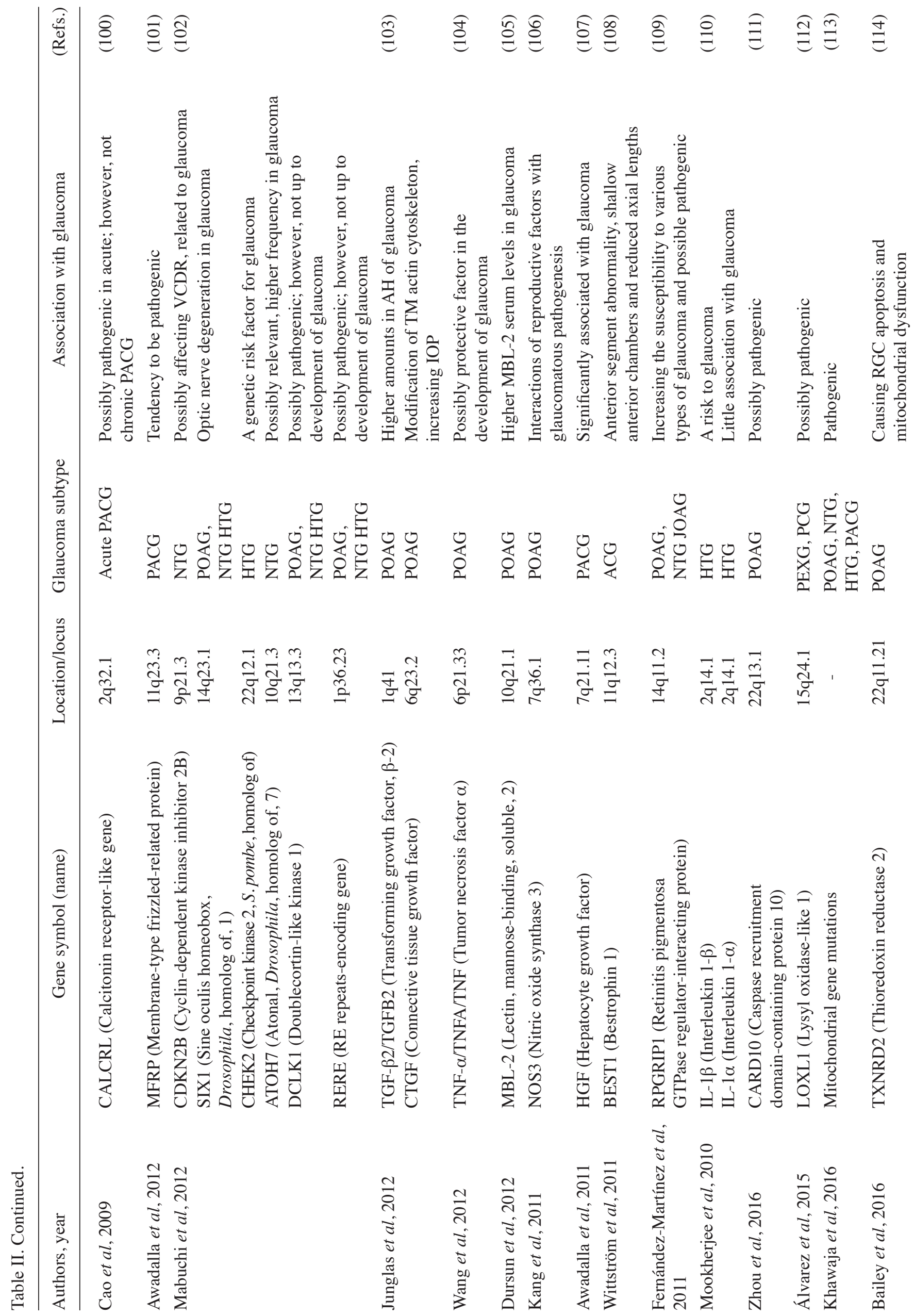




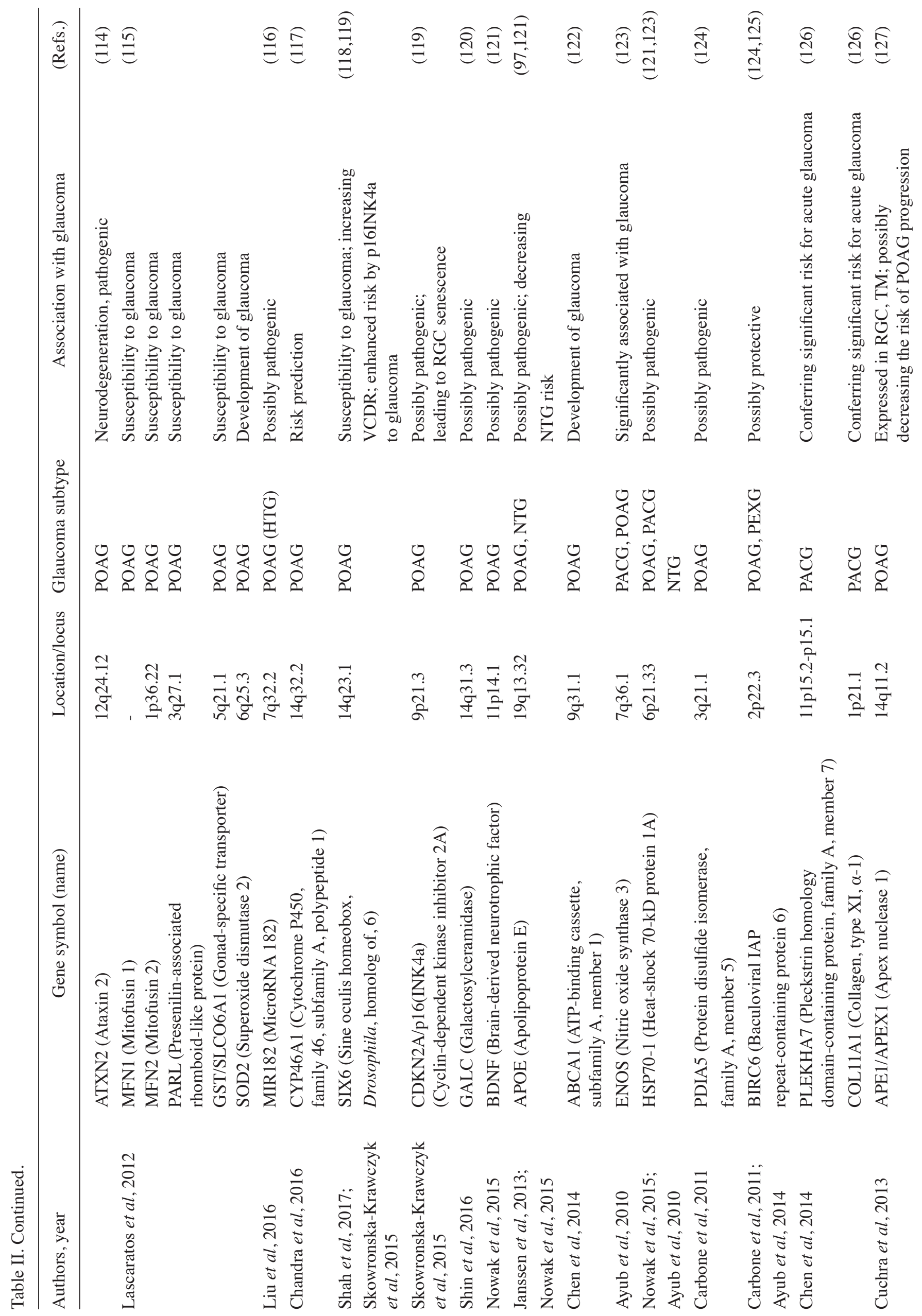




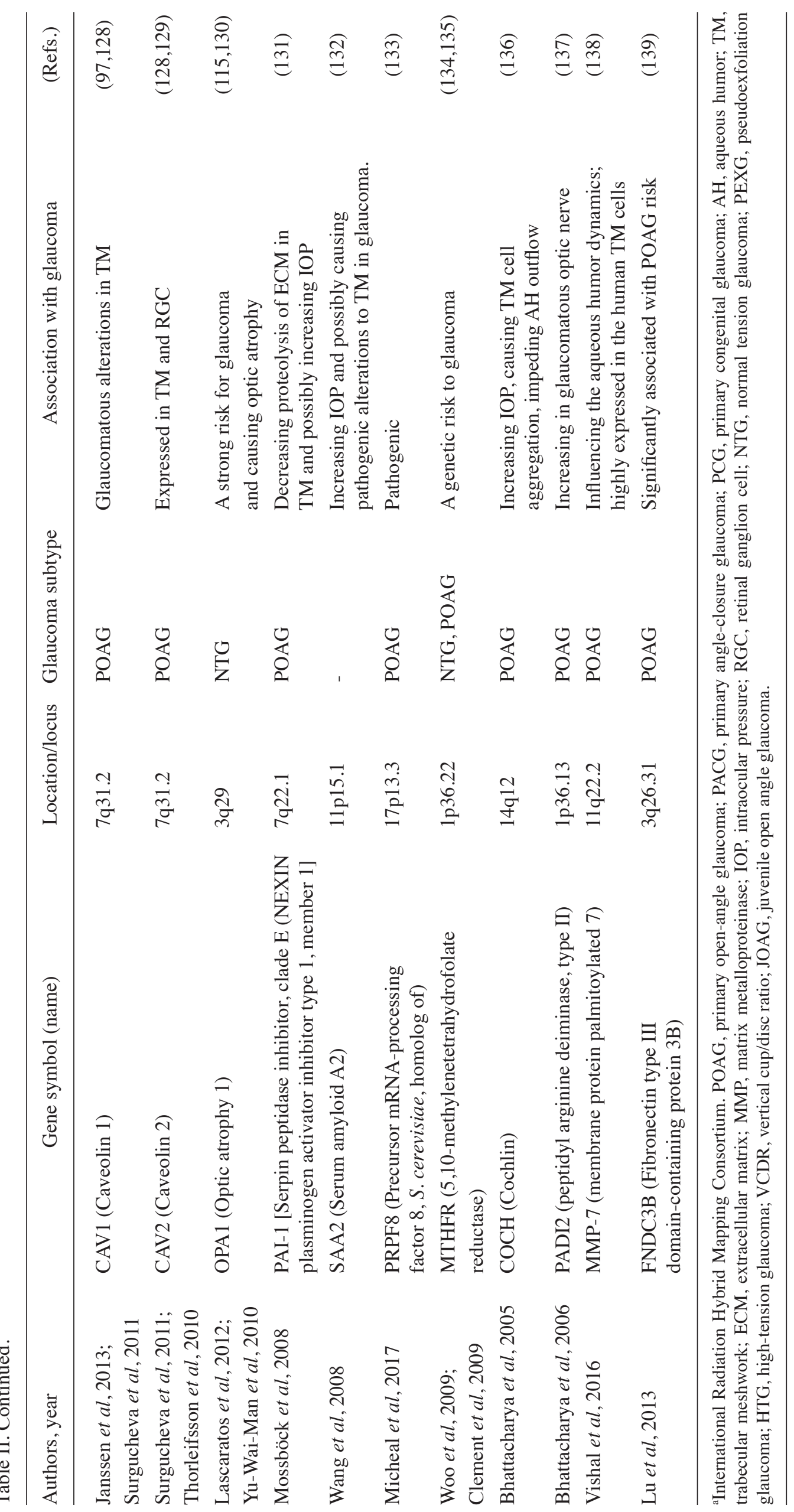


TIGR (trabecular meshwork-induced glucocorticoid response protein) (147). Under stress, eyes may produce the MYOC protein in increased amounts, suggesting that MYOC may serve a protective role similar to a molecular chaperone (148). The MYOC protein is produced by numerous ocular tissues $(43,73,149)$, including the ciliary body, trabecular meshwork (TM), optic nerve, LC, cornea, iris, sclera, retina and lens, and is usually visualized in muscles, including the ciliary muscle, iris and smooth muscle. MYOC is additionally secreted into the vitreous humor for undetermined reasons. Stone et al (64) suggested that there is a possible association of the muscle-associated ciliary body with increased IOP. MYOC expression does not exhibit a significant difference in the blood of patients with POAG compared with blood from individuals without POAG; however, there is a significant difference in the TM (150). Therefore MYOC expression may account for a genetic susceptibility to POAG in specific tissues, including the ciliary body and TM.

Pathogenesis of MYOC. The pathogenesis of MYOC mutations is unclear; however, the three most possible causes for glaucoma are as follows. In the unhealthy state, there is poor normal MYOC protein secretion. MYOC mutations may lead to accumulation of mutated MYOC proteins within the TM (151-154). Retention of abnormal MYOC protein may be harmful to TM cells and result in their dysfunction or death, which may obstruct $\mathrm{AH}$ outflow, and consequently increase IOP $(43,64,147,155,156)$. In addition, accumulation of mutated MYOC proteins in the endoplasmic reticulum activates the unfolded protein response (UPR) in TM cells (157), subsequently leading to apoptosis that may cause high IOP. Over activated UPR may lead to certain neurodegenerative diseases, and inhibiting UPR is a possible therapy for these diseases (158). Thus, this method may additionally be applicable to glaucoma. Normal MYOC is involved in exosome shedding into the aqueous humor, and exosomes are associated with paracrine and autocrine signaling (74), that therefore may serve as vehicles of MYOC protein trafficking. Notably, normal MYOC protein is absent in the aqueous humor of glaucomatous patients with pathogenic MYOC mutations (151). Thus, another prevalent hypothesis on the pathogenesis of MYOC mutations is that they interfere with MYOC protein trafficking and lead to the intracellular aggregation of the misfolded MYOC protein (74). Accumulation of misfolded MYOC proteins decreases AH out flow, and that influences IOP regulation; however, its mechanism is unclear (74). The third hypothesis is regarding specific interactions between MYOC mutations and mitochondria in the TM $(159,160)$. A subsequent study indicated that MYOC mutations lead to dysregulation of calcium channels resulting in mitochondrial depolarization in the TM, consequently resulting in TM contraction, which decreases AH outflow and further causes increased IOP (161).

Digenic and polygenic mechanism of MYOC. There is strong evidence that only $\sim 5 \%$ of POAG (65) is caused by a single gene, and other cases of POAG are caused by digenic or polygenic cooperation mechanisms, none of which may alone cause glaucoma. Usually, cooperation of MYOC mutations with one or more genes contributes to glaucoma. Mutations in MYOC, OPTN and CYP1B1 are identified to coexist in $\sim 3.59 \%$ of POAG cases (162). This demonstrates that mutations in the three genes together may be involved in the pathogenesis of POAG. There are other studies investigating the association between MYOC and OPTN. OPTN and MYOC are observed in POAG $(69,162-166)$, exfoliative glaucoma (164) and exfoliation syndrome (164). Overexpression of OPTN may upregulate MYOC in TM and stabilize MYOC mRNA (167). There is a possible polygenic interaction among MYOC, OPTN and apolipoprotein E (APOE). Disease-causing mutations in MYOC and OPTN contribute to only a small number of Chinese POAG cases (163). However, common polymorphisms in MYOC, OPTN $(69,163,166)$, APOE $(69,163)$ and WDR36 (69) may together account for POAG. Common polymorphisms of these genes are not associated with POAG alone; however, they may cooperatively contribute to the disease, which indicates a polygenic pathogenesis. A study reported that the mean onset age of carriers with only MYOC mutations is 51 years; however, the mean onset age of carriers with MYOC and CYP1B1 mutations is 27 years (168). This indicates that mutations in the two genes may interact to advance the onset age of glaucoma. Notably, in a study (169) Gln48His, a MYOC mutation, was observed in POAG and PCG; however, one patient with PCG had a CYP1B1 mutation (Arg368His), and the other patient with PCG had none of the CYP1B1 mutations. These results demonstrate that there is a possible digenic interaction between MYOC and CYP1B1, without excluding the possibility that there has been an unidentified gene associated with glaucoma. However, another study reported that none of the CYP1B1 mutations was observed in all five POAG cases with MYOC mutations (170). Forkhead box $\mathrm{C} 1$ (FOXC1) may regulate MYOC secretion through modulation of RAB3 GTPase-activating protein catalytic subunit $1 \mathrm{RAB}$, synaptosomal-associated protein 25-kD and RAB3 GTPase-activating protein noncatalytic subunit (144). A different study (171) suggested that MYOC and FOXC1 mutations are not associated with the pathogenesis of PCG. The mutations Leu486Phe in MYOC and Val108Ile in UDP-Gal: $\beta$ GlcNAc $\beta$-1,4-galactosyltransferase polypeptide 3 may cooperatively contribute to the pathogenesis of POAG (94).

\section{Pathogenic genes in the GLC1B-GLC1Q loci}

OPTN. OPTN, widely expressed in retinal ganglion cells (172), the nonpigmented ciliary epithelium, human TM and the retina (77), is an autophagy receptor. Autophagy may remove damaged organelles and proteins via lysosomal degradation (172). Autophagy and membrane vesicle trafficking serve an important role in the regulation of OPTN functions (172). Furthermore, the level of autophagy mediated through OPTN is very important for the survival of retinal cells (172). Mutations in OPTN are involved in POAG (172). Another conclusion contradicted this result, reporting that OPTN is not associated with POAG in Spain (173). Of these disease-causing mutations, two are noteworthy, Glu50Lys and Met98Lys.

The frequency of Glu50Lys in POAG is $13.5 \%$ (77). Notably, $81.6 \%$ of POAG cases with recurrent Glu50Lys have normal IOP; whereas only $18.4 \%$ of those have increased IOP (77). However, another study suggested that OPTN mutations are involved in POAG rather than glaucoma with normal IOP in Japanese patients (174). Glu50Lys impairs autophagy (172) and trafficking $(172,175)$, resulting in the 
death of retinal cells through apoptosis (172) and disrupting the endocytic recycling that is very important for maintaining homeostasis (175).

Rezaie et al (77) first reported that Met98Lys is a risk-causing mutation for POAG, and the frequency of Met98Lys in POAG (13.6\%) is significantly higher compared with controls (2.1\%). In another study by Sripriya et al (176), Met98Lys was not identified in controls; however, it was identified in POAG (4.1\%) and NTG (6\%) (162). Mukhopadhyay et al (177) did not detect Met98Lys in NTG, and the frequency of Met98Lys was $11 \%$ in POAG and $5.5 \%$ in controls. An alternative study (162) presented the contrary conclusion that Met98Lys may not be a risk-causing factor for POAG on account of a very similar frequency in POAG (7.97\%) and controls (7.29\%). Met98Lys is usually known as a disease-causing mutation and the majority of POAG cases with Met98Lys additionally have normal IOP, similar to Glu50Lys (77). The possible pathogenesis of Met98Lys is that it may impair autophagy, which consequently leads to the death of retinal cells through apoptosis and transferrin receptor degradation (172). However, the pathogenic mechanism of glaucoma-causing Met98Lys requires further research and examination.

WDR36. WDR36, located within the POAG linkage locus GLC1G and first identified by Monemi et al (78), is widely expressed in numerous ocular tissues, including the optic nerve, ciliary body, retina, TM, ciliary muscles, iris, lens and sclera. Monemi et al (78) formerly suggested that the frequency of WDR36 mutations in POAG is $1.6-17 \%$. There is a possible association of WDR36 with the pathogenic mechanism of HTG $(67,68)$. WDR36 mutations may alter the cell phenotype supporting the theory that WDR36 is associated with the polygenic pathogenesis of glaucoma (178). To date, WDR36 importance remains unclear; furthermore, its pathogenicity is controversial. As subsequent studies did not demonstrate WDR36 mutations to be POAG-causing mutations, it was demonstrated that WDR36 mutations may only be a risk factor for POAG (67-69). In addition, Fingert et al (179) were not able to confirm the association of WDR36 with pathogenesis of POAG.

NTF4, ASB10, EFEMP1 and IL20RB. NTF4, located within the POAG linkage locus GLC1O, is localized to RGCs (70). Pasutto et al (70) suggested that the frequency of NTF4 mutations in POAG is $1.7 \%$ and there is strong genetic evidence that NTF4 mutations are involved in POAG of European origin. Liu et al (180) additionally identified coding alterations in five POAG cases and 12 controls of European origin from Southeastern USA, of which two mutations were previously detected by Pasutto et al (70). Therefore, Liu et al concluded that these NTF4 coding alterations are not significantly associated with the pathogenesis of POAG. In addition, another study by Chen et al (181) suggested that NTF4 does not mainly contribute to the molecular genetics of POAG. From the above, the association of NTF4 mutations with POAG pathogenesis remains to be investigated. In addition, besides the European origin, NTF4 mutations have been identified in Chinese populations (182). This indicates that NTF4 mutations may derive from multiple ancestors.
ASB10, located within the POAG linkage locus GLC1F (183), influences AH outflow (71). ASB10 is most highly expressed in the iris, followed by human TM, RGCs, the ciliary body, choroid, optic nerve, retina, lamina and a little in the lens (71). Among patients with POAG and controls, the frequency of ASB10 mutations is 6 and 2.8\%, respectively (71). To test whether ASB10 influences AH drainage, Pasutto et al (71) applied RNA interference silencing for knockdown of ASB10 mRNA expression in perfused human anterior segment cultures. The results revealed that the decrease in AH outflow facility was $\sim 50 \%$. In addition, ASB10 may be involved in the ubiquitin-mediated degradation pathways through interactions of ASB10 with the $\alpha 4$ subunit of the 20s proteasome and with HSP70 in TM (184).

EFEMP1, located within the POAG linkage locus GLC1H, is a plausible candidate for POAG (185). Although there have been a few efforts to confirm the linkage to GLC1H, it remains uncertain. Mutations in EFEMP1 are involved in decreasing the optic disc area (186). Another mutation, c.418C $>\mathrm{T}$ in EFEMP1 may be predictive for POAG (185). Expression of EFEMP1 may be influenced by transforming growth factor (TGF)- $\beta 2$. A study by Junglas et al (187) reported that TGF- $\beta 2$ is more highly expressed in AH of POAG and maybe associated with the increase in AH outflow resistance in POAG. Higher amounts of TGF- $\beta 2$ inhibit the expression of EFEMP1 (188).

IL20RB, located within the POAG linkage locus GLC1C, has a role in POAG pathogenesis (189). An IL20RB mutation, Thr104 Met, lying in an active binding site of IL20RB (190), has been observed in a large POAG family (189); therefore, this additionally demonstrates that IL20RB may be implicated in the pathogenesis of POAG. According to OMIM (no. 605621), IL20RB is highly expressed in human skin and testes, and less expressed in the muscle, placenta, heart, ovary and lung. Recently, IL20RB was detected to be additionally expressed in human TM (191). To the best of the authors' knowledge, thus far, little research effort has been made to investigate IL20RB as a POAG-causing gene.

\section{Pathogenic genes in the GLC3A-GLC3E loci}

CYP1B1. In humans, the CYP1B1 gene encodes cytochrome $\mathrm{P} 450 \mathrm{BB}$, and is regulated via the aryl hydrocarbon receptor. CYP1B1 was the first gene identified in PCG-associated loci (GLC3A-3E) (192), and its role has been clearly understood (65). CYP1B1 is widely expressed in the eyes, including the retina, iris, ciliary body and TM (193). However, certain previous studies suggested that CYP1B1 is not expressed in TM at any stage of eye development (194). CYP1B1 has been thought to be significantly associated with human fetal eye development (194). To date, at least 147 CYP1B1 mutations have been identified globally in 542 patients with PCG in various countries, including Brazil, China, India, Iran, Morocco, Russia, Saudi Arabia, Slovak Gypsy populations, Turkey, USA, Spain, Pakistan, Oman, the Netherlands, Mexico, Kuwait, Japan, Israel, Indonesia, Germany, Ecuador, Canada, Britain and Algeria $(6,195)$. Among CYP1B1 mutations, Glu387Lys has been traced to a common genetic origin for PCG (196). CYP1B1 mutations, which have been reportedly associated with a wider range of glaucomatous phenotypes, including PCG (6,169,195-197), POAG (198-200), JOAG (201) 
and PEXG (199), appear in patients with glaucoma at a higher frequency compared with other glaucoma-associated genes (199). CYP1B1 mutations may confer increased susceptibility to PCG and are the most common pathogenic factors of PCG (6). However, the frequency of PCG-causing mutations in CYP1B1 varies significantly in different populations, including Mexican (<10\%) (202), Vietnamese (16.7\%) (197), Chinese, Japanese and Indonesian (all 20\%) (202), Indian (40\%) (169). Furthermore, PCG-causing mutations in CYP1B1 occur with extremely high incidence in Slovak Gypsy and Saudi Arabian populations (202), which supports an additional study reporting that consanguinity is a fundamental mechanism for high PCG incidence in Slovak Gypsy and Saudi Arabian populations (203) Available data demonstrate that CYP1B1 may not be the primary disease-causing gene for glaucoma in East Asians and South East Asians, unlike in Gypsy and Saudi Arabian populations. Furthermore, PCG in Mexicans may not be caused by CYP1B1 mutations. In addition, only $\sim 10 \%$ of cases of POAG in Mexico harbor CYP1B1 mutations (198), demonstrating that CYP1B1 mutations may not be the cause of the pathogenesis of POAG; however, dysfunction of CYP1B1 may increase the risk of POAG. A low percentage of JOAG cases $(\sim 5 \%)$ harbor CYP1B1 mutations (168), and CYP1B1 possibly contributes to JOAG in a monogenic model (201).

An increasing amount of research attention is focusing on the interactions of CYP1B1 with other genes. There is growing evidence that interactions of CYP1B1 with MYOC occur in patients with PCG $(169,204)$. In the process of interactions, MYOC is a potential modifier gene (205). In addition, TEK mutations co-occur with CYP1B1 mutations in patients with PCG; notably, the parents of these patients with PCG harbor either heterozygous CYP1B1 or TEK alleles and are asymptomatic (206). Furthermore, there is strong evidence suggesting that the interaction between CYP1B1 and TEK accounts for the pathogenesis of PCG (206); however, the mode of interaction remains unclear regarding whether an overlapping or independent mode is involved in the pathogenic mechanism of PCG. The interaction of CYP1B1 with MYOC and TEK, respectively, in the pathogenesis of PCG further lends support to the digenic inheritance of PCG.

Although CYP1B1 mutations are the most common cause of PCG, these mutations only contribute to a very small proportion of the total amount of PCG (6). Besides CYP1B1, there are a number of genes demonstrated to be associated with PCG, including LTBP2, FOXC1 and MYOC. Therefore, it is reasonable to speculate that other genes may participate in the pathogenesis of PCG; however, there still remain a large number of unknown genes requiring identification.

LTBP2. LTBP2, located within the PCG linkage locus GLC3D, is the largest member of the latent TGF- $\beta$ family whose signaling failure in the anterior and posterior eye may cause pathogenic alterations in POAG (84). LTBP2 is most highly expressed in the lens capsule (192), secondly in the TM and ciliary processes $(82,192)$ that are thought to be associated with PCG pathogenesis, with a very small amount in the sclera, corneal stroma and iris (192). LTBP2 mutations are identified in different populations, including Pakistani (82), Indian (207), Gypsy (82), Iranian, Moroccan, and Saudi Arabian populations (OMIM). From the aforementioned data, LTBP2 mutations appear to derive from West Asia and South Asia. Although Morocco is located in Africa, $75 \%$ of Moroccans are of Arabic descent; furthermore, the origin of the Gypsy ethnicity is thought to be in Ancient India. To the best of our knowledge, LTBP2 mutations have been not observed in other populations. Therefore, it is reasonable to hypothesize that LTBP2 mutations may have the same ancestor.

LTBP2 is a disease-causing gene for PCG (192) and is very important in the development of the anterior chamber of the human eye, where LTBP2 possibly serves a role in maintaining ciliary muscle tone (82). Besides PCG, LTBP2 mutations maybe associated with PACG and POAG (208). Therefore, there may be an overlap in the pathogenic mechanism among various types of glaucoma. It is this overlap that may account for the common characteristics among these various types of glaucoma, including optic nerve impairment and decreased vision, and for the common clinical presentation at onset, including eye pain, red-eye, blurred vision, nausea and mid-dilated pupils. However, another study (207) had contrary conclusions that LTBP2 mutations are not implicated in the pathogenesis of PCG. In addition, LTBP2 is not thought to be a disease-causing gene for PCG in the Han Chinese population (209).

TEK. TEK, located within the PCG linkage locus GLC3E, is an angiopoietin receptor, additionally termed cluster of differentiation 202B and tyrosine kinase with immunoglobulin-like and EGF-like domains 2, and may regulate vascular homeostasis (210). Although TEK and other vascular growth factors are important for AH outflow and Schlemm's canal development, their association with glaucoma remains unclear (211). A 50\% decrease in TEK adequately demonstrated defective Schlemm's canal development and impaired AH outflow (210), and this demonstrates that TEK concentration is important for the $\mathrm{AH}$ drainage pathways. Variable expression of TEK is possibly produced by oligogenic or digenic inheritance, in line with other ocular disorders of developmental origin produced by mutations in optic atrophy $1, \mathrm{FOXC} 1$, paired box gene 6 and MYOC (210). In addition, another recent study demonstrated that TEK mutations co-occur with CYP1B1 mutations in PCG (206), and demonstrated that interactions between TEK and CYP1B1 account for digenic inheritance in PCG pathogenesis.

\section{Potential pathogenic mechanism and recent advances in treatments}

Potential pathological mechanism. Among the 96 genes, mutations of MYOC (GLC1A) and CYP1B1 (GLC3A) have the closest associations with potential pathological mechanisms in glaucoma. Besides the aforementioned glaucomatous pathogenesis, a novel pathogenic mechanism for MYOC-associated glaucoma is proposed. Extracellular matrix (ECM) proteins of TM are synthesized in the endoplasmic reticulum (ER) and finally secreted into the ECM. Malfunction of the ER during ER stress caused by mutant myocilin accumulation in the ER may affect ECM protein processing and secretion, which results in aberrant intracellular accumulation of ECM proteins in TM (212). The 
accumulation of ECM proteins may deteriorate ER stress, leading to TM cell dysfunction and obstructing AH outflow, thereby increasing IOP (212).

CYP1B1 defects cause angle abnormalities involving TM and Schlemm's canal (213). CYP1B1 mutations lower activity or stability of the enzyme in the mitochondria $(214,215)$ and reduce expression levels of ECM proteins in TM (215). These may impact the development or filtering function of TM. In addition, abnormal mitochondria caused by CYP1B1 mutations [the same case as with MYOC mutations (161)] may cause dysregulation of calcium channels resulting in mitochondrial depolarization in TM, consequent TM contraction, reduction of AH outflow and an increase in IOP.

Recent advances in treatment. Based on previous studies on the potential pathogenic mechanism of MYOC mutation, at present, there have been three novel approaches to treatment for MYOC-associated POAG: i) Using chemical chaperones (based on molecular mechanisms) to decrease misfolding or unfolding of proteins and increase MYOC secretion (216); ii) given the gain-of-function nature of MYOC mutations, another novel approach is targeting MYOC mRNA or the myocilin protein (216); and iii) targeting MYOC by gene editing with clustered regularly interspaced short palindromic repeats-Cas9 technology to reduce ER stress and lower IOP (216).

According to previous studies on potential pathogenic mechanisms of CYP1B1 mutation, researchers developed two novel therapies: One is the approach based on the gene, directly attempting to correct or replace abnormal CYP1B1 (217); the more novel approach differentiates into a specific lineage and transfers stem cells containing wild-type CYP1B1 to stimulate the normal development of TM cells (217).

\section{Conclusion and prospects}

As mentioned, the pathogenic mechanism of MYOC- or CYP1B1-associated glaucoma is associated with aberrant ECM proteins in TM. The accumulation of deposits of ECM proteins may lead to ER stress as described, resulting in the misfolding or unfolding of MYOC proteins. If ER stress is too severe or if UPR (an adaptive response to ER stress) fails to compensate for the ER stress, dysfunction and apoptosis occurs (218-221), which may cause increased IOP. At present, the novel protein-remodeling factors as potential therapeutics are highly promising to correct the misfolding or unfolding of proteins in neurodegenerative diseases or disorders (221). Therefore, as glaucoma is a neurodegenerative disease, the highly promising protein-remodeling factors (including engineered Hsp104 mutations) may be useful in the development of novel glaucoma therapies, and to better understand the glaucomatous mechanism.

Additionally, combined with the prospect for glaucoma healthcare, certain important problems require addressing in future studies. More in vivo animal models (monkey, pig and cow, whose eyes are similar to human), with stem cell-based studies on glaucoma-associated genes, including MYOC and CYP1B1, are required. In addition, using autologous stem cells, including bone marrow derived stem cells (217), that have been genetically modified to serve an important role in the pathogenic mechanism of glaucoma may be a promising future therapy for MYOC- or CYP1B1-associated glaucoma.

In conclusion, strong evidence indicates that genes are significantly associated with the pathogenesis of glaucoma, and additionally provides a stimulus for the identification of these pathogenic genes. Further efforts to research clinical trials on potential feasible therapeutic targets are necessary, which may construct future therapeutic paradigms for glaucoma. Presently, although a number of genes have been identified to be associated with glaucoma, their pathogenic mechanisms remain unclear, with the exception of MYOC and CYP1B1. Furthermore, certain studies are controversial, even contradictory. Therefore, further research is required to better comprehend the association between pathogenic genes and glaucoma.

\section{Acknowledgements}

The authors would like to acknowledge the Laboratory of Qiqihar Medical University (Heilongjiang, China) for provision of the relevant literature.

\section{Funding}

The present study was supported by a grant from Taizhou Science and Technology Support Projects for Social Development (2016) of Taizhou Science and Technology Bureau (grant no. SSF20160112).

\section{Availability of data and materials}

Not applicable.

\section{Authors' contributions}

H-WW produced the manuscript. H-WW, PS and FG conceived and designed framework of this article. YC, L-PJ, WZ and H-PW collected and analyzed the literature.

\section{Ethics approval and consent to participate}

Not applicable.

\section{Consent for publication}

Not applicable.

\section{Competing interests}

The authors declare that they have no competing interests.

\section{References}

1. Quigley HA and Broman AT: The number of people with glaucoma worldwide in 2010 and 2020. Br J Ophthalmo 190: 262-267, 2006.

2. Foris LA and Gossman WG: Glaucoma, open angle. StatPearls Publishing Internet, Nov 21, 2018.

3. Kumar S, Malik MA, K S, Sihota R and Kaur J: Genetic variants associated with primary open angle glaucoma in Indian population. Genomic 109: 27-35, 2017.

4. Tham YC, Li X, Wong TY, Quigley HA, Aung T and Cheng CY: Global prevalence of glaucoma and projections of glaucoma burden through 2040: A systematic review and meta-analysis. Ophthalmology 121: 2081-2090, 2014 
5. Mantravadi AV and Vadhar N: Glaucoma. Prim Care 42: 437-449, 2015.

6. Faiq M, Sharma R, Dada R, Mohanty K, Saluja D and Dada T: Genetic biochemical and clinical insights into primary congenital glaucoma. J Curr Glaucoma Pract 7: 66-84, 2013.

7. Le A, Mukesh BN, McCarty CA and Taylor HR: Risk factors associated with the incidence of open-angle glaucoma: The visual impairment project. Invest Ophthalmol Vis Sci 44: 3783-3789, 2003

8. Suzuki Y, Iwase A, Araie M, Yamamoto T, Abe H, Shirato S, Kuwayama Y, Mishima HK, Shimizu H, Tomita G, et al: Risk factors for open-angle glaucoma in a Japanese population: The Tajimi Study. Ophthalmology 113: 1613-1617, 2006.

9. European Glaucoma Prevention Study (EGPS) Group, Miglior S, Pfeiffer N, Torri V, Zeyen T, Cunha-Vaz J and Adamsons I: Predictive factors for open-angle glaucoma among patients with ocular hypertension in the European Glaucoma. Prevention study Ophthalmology 114: 3-9, 2007.

10. Dewundara SS, Wiggs JL, Sullivan DA and Pasquale LR: Is estrogen a therapeutic target for glaucoma? Semin Ophthalmol 31: 140-146, 2016.

11. McMonnies CW: Glaucoma history and risk factors. J Optom 10: 71-78, 2017.

12. Cho HK and Kee C: Population-based glaucoma studies in Asians. Surv Ophthalmol 59: 434-447, 2014.

13. Flammer J, Pache M and Resink T: Vasospasm, its role in the pathogenesis of diseases with particular reference to the eye. Prog Ret Eye Res 20: 319-349, 2001.

14. Mitchell P, Lee AJ, Wang JJ and Rochtchina E: Intraocular pressure over the clinical range of blood pressure: Blue mountains eye study findings. Am J Ophthalmol 140: 131-132, 2005.

15. Zhou M, Wang W, Huang W and Zhang X: Diabetes mellitus as a risk factor for open-angle glaucoma: A systematic review and meta-analysis. PLoS One 9: e102972, 2014.

16. Congdon N, Wang F and Tielsch JM: Issues in the epidemiology and population-based screening of primary angle-closure glaucoma. Surv Ophthalmol 36: 411-423, 1992.

17. Doucette LP, Rasnitsyn A, Seifi M and Walter MA: The interactions of genes, age, and environment in glaucoma pathogenesis. Surv Ophthalmol 60: 310-326, 2015

18. Ma F, Dai J and Sun X: Progress in understanding the association between high myopia and primary open-angle glaucoma. Clin Exp Ophthalmol 42: 190-197, 2014.

19. Xu L, Fang WF, Wang YX, Chen CX and Jonas JB: Anterior chamber depth and chamber angle and their associations with ocular and general parameters: The Beijing eye study. Am J Ophthalmol 145: 929-936, 2008.

20. Topouzis F, Coleman AL, Harris A, Jonescu-Cuypers C, Yu F Mavroudis L, Anastasopoulos E, Pappas T, Koskosas A and Wilson MR: Association of blood pressure status with the optic disk structure in non-glaucoma subjects: The Thessaloniki eye study. Am J Ophthalmol 142: 60-67, 2006.

21. Leske MC, Wu S-Y, Hennis A, Honkanen R and Nemesure B; BESs Study Group: Risk factors for incident open-angle glaucoma: The Barbados eye studies. Ophthalmology 115: 85-93, 2008.

22. Gordon MO, Beiser JA, Brandt JD, Heuer DK, Higginbotham EJ, Johnson CA, Keltner JL, Miller JP, Parrish RK II, Wilson MR and Kass MA: The ocular hypertension treatment study: Baseline factors that predict the onset of primary open-angle glaucoma Arch Ophthalmol 120: 714-720; discussion 829-830, 2002.

23. Racette L, Wilson MR, Zangwill LM, Weinreb RN and Sample PA: Primary open-angle glaucoma in blacks: A review. Surv Ophthalmol 48: 295-313, 2003.

24. Cursiefen C, Wisse M, Cursiefen S, Jünemann A, Martus P and Korth M: Migraine and tension headache in high-pressure and normal-pressure glaucoma. Am J Ophthalmol 129: 102-104, 2000.

25. Farrar SM, Shields MB, Miller KN and Stoup CM: Risk factors for the development and severity of glaucoma in the pigment dispersion syndrome. Am J Ophthalmol 108: 223-229, 1989.

26. Astafurov K, Elhawy E, Ren L, Dong CQ, Igboin C, Hyman L, Griffen A, Mittag T and Danias J: Oral microbiome link to neurodegeneration in glaucoma. PLoS One 9: e104416, 2014.

27. Bailey JN, Yaspan BL, Pasquale LR, Hauser MA, Kang JH, Loomis SJ, Brilliant M, Budenz DL, Christen WG, Fingert J, et al: Hypothesis-independent pathway analysis implicates GABA and acetyl-CoA metabolism in primary open-angle glaucoma and normal-pressure glaucoma. Hum Genet 133: 1319-1330, 2014.
28. Konieczka K, Todorova MG, Chackathayil TN and Henrich PB: Cilioretinal artery occlusion in a young patient with flammer syndrome and increased retinal venous pressure. Klin Monbl Augenheilkd 232: 576-578, 2015.

29. Liao Q, Sun XY, Guo H and Li C: Exploring the potential mechanism and screening small molecule drugs for glaucoma by using bioinformatics approach. Eur Rev Med Pharmacol Sci 18: 132-140, 2014.

30. Kurtz S, Regenbogen M, Goldiner I, Horowitz N and Moshkowitz M: No association between Helicobacter pylori infection or CagA-bearing strains and glaucoma. J Glaucoma 17: 223-226, 2008

31. Jindal V: Glaucoma: An extension of various chronic neurodegenerative disorders. Mol Neurobiol 48: 186-189, 2013

32. Wang M, Lin HT, Bai YJ, Ge J and Zhuo YH: Clinical evidence in concurrence of retinitis pigmentosa and glaucoma. Chin Med J Engl 124: 1270-1274, 2011.

33. Lee S, Van Bergen NJ, Kong GY, Chrysostomou V, Waugh HS, O'Neill EC, Crowston JG and Trounce IA: Mitochondrial dysfunction in glaucoma and emerging bioenergetic therapies. Exp Eye Res 93: 204-212, 2011

34. Lin CC, Hu CC, Ho JD, Chiu HW and Lin HC: Obstructive sleep apnea and increased risk of glaucoma: A population-based matched-cohort study. Ophthalmology 120: 1559-1564, 2013.

35. Leske MC: The epidemiology of open-angle glaucoma: A review. Am J Epidemiol 118: 166-186, 1983.

36. Lachkar Y and Bouassida W: Drug-induced acute angle closure glaucoma. Curr Opin Ophthalmol 18: 129-133, 2007.

37. Jones R III and Rhee DJ: Corticosteroid-induced ocular hypertension and glaucoma: A brief review and update of the literature. Curr Opin Ophthalmol 17: 163-167, 2006.

38. McMonnies CW: An examination of the hypothesis that intraocular pressure elevation episodes can have prognostic significance in glaucoma suspects. J Optom 8: 223-231, 2014.

39. McMonnies CW: Intraocular pressure spikes in keratectasia axial myopia and glaucoma. Optom Vis Sc 85: 1018-1026, 2008.

40. Li M, Wang M, Guo W, Wang J and Sun X: The effect of caffeine on intraocular pressure: A systematic review and meta-analysis. Graefes Arch Clin Exp Ophthalmol 249: 435-442, 2011.

41. Sommer A, Tielsch JM, Katz J, Quigley HA, Gottsch JD, Javitt $J$ and Singh K: Relationship between intraocular pressure and primary open angle glaucoma among white and black Americans. The Baltimore Eye Survey. Arch Ophthalmol 109: 1090-1095, 1991.

42. Weinreb RN, Aung T and Medeiros FA: The pathophysiology and treatment of glaucoma: A review. JAMA 311: 1901-1911, 2014.

43. Fingert JH: Primary open-angle glaucoma genes. Eye Lond 25 : 587-595, 2011.

44. Teikari JM, Airaksinen PJ, Kaprio J and Koskenvuo M: Primary open-angle glaucoma in 2 monozygotic twin pairs. Acta Ophthalmol Copenh 65: 607-611, 1987.

45. Biró I: Notes on the heredity of glaucoma. Ophthalmologica 98: 43-50, 1939

46. Ahram DF, Alward WL and Kuehn MH: The genetic mechanisms of primary angle closure glaucoma. Eye Lond 29: 1251-1259, 2015.

47. King A, Azuara-Blanco A and Tuulonen A: Glaucoma. BMJ 346: f 3518,2013

48. Friedman DS, Wolfs RC, O'Colmain BJ, Klein BE, Taylor HR, West S, Leske MC, Mitchell P, Congdon N and Kempen J; Eye Diseases Prevalence Research Group: Prevalence of open-angle glaucoma among adults in the United States. Arch Ophthalmol 122: 532-538, 2004.

49. He M, Foster PJ, Ge J, Huang W, Zheng Y, Friedman DS, Lee PS and Khaw PT: Prevalence and clinical characteristics of glaucoma in adult Chinese: A population-based study in Liwan District, Guangzhou. Invest Ophthalmol Vis Sci 47: 2782-2788, 2006.

50. Abu-Amero K, Kondkar AA and Chalam KV: An updated review on the genetics of primary open angle glaucoma. Int J Mol Sci 16: 28886-28911, 2015

51. Friedman DS, Jampel HD, Muñoz B and West SK: The prevalence of open-angle glaucoma among blacks and whites 73 years and older: The salisbury eye evaluation glaucoma study. Arch Ophthalmol 124: 1625-1630, 2006.

52. Mukesh BN, McCarty CA, Rait JL and Taylor HR: Five-year incidence of open-angle glaucoma: The visual impairment project. Ophthalmology 109: 1047-1051, 2002. 
53. de Voogd S, Ikram MK, Wolfs RC, Jansonius NM, Hofman A and de Jong PT: Incidence of open-angle glaucoma in a general elderly population: The rotterdam study. Ophthalmology 112: 1487-1493, 2005

54. Wang X, Harmon J, Zabrieskie N, Chen Y, Grob S, Williams B, Lee C, Kasuga D, Shaw PX, Buehler J, et al: Using the utah population database to assess familial risk of primary open angle glaucoma. Vis Res 50: 2391-2395, 2010.

55. Lowe RF: Primary angle-closure glaucoma. Inheritance and environment. Br J Ophthalmol 56: 13-20, 1972.

56. Alsbirk PH: Anterior chamber depth and primary angle-closure glaucoma. II. A genetic study. Acta Ophthalmol Copenh 53: 436-449, 1975.

57. Alsbirk PH: Anterior chamber depth and primary angle-closure glaucoma. I. An epidemiologic study in Greenland Eskimos. Acta Ophthalmol Copenh 53: 89-104, 1975.

58. Alsbirk PH: Primary angle-closure glaucoma. Oculometry, epidemiology, and genetics in a high risk population. Acta Ophthalmol Suppl: 5-31, 1976.

59. Hu CN: An epidemiologic study of glaucoma in Shunyi County Beijing. Zhonghua Yan Ke Za Zhi 25: 115-119, 1989 (In Chinese)

60. He M, Wang D, Zheng Y, Zhang J, Yin Q, Huang W, Mackey DA and Foster PJ: Heritability of anterior chamber depth as an intermediate phenotype of angle-closure in Chinese: The Guangzhou twin eye study. Invest Ophthalmol Vis Sci 49: 81-86, 2008.

61. van Koolwijk LM, Despriet DD, van Duijn CM, Pardo Cortes LM Vingerling JR, Aulchenko YS, Oostra BA, Klaver CC and Lemij HG: Genetic contributions to glaucoma: Heritability of intraocular pressure, retinal nerve fiber layer thickness, and optic disc morphology. Invest Ophthalmol Vis Sci 48: 3669-3676, 2007.

62. Day AC, Baio G, Gazzard G, Bunce C, Azuara-Blanco A Munoz B, Friedman DS and Foster PJ: The prevalence of primary angle closure glaucoma in European derived populations: A systematic review. Br J Ophthalmol 96: 1162-1167, 2012.

63. Liu Y and Allingham RR: Major review: Molecular genetics of primary open-angle glaucoma. Exp Eye Res 160: 62-84, 2017.

64. Stone EM, Fingert JH, Alward WL, Nguyen TD, Polansky JR Sunden SL, Nishimura D, Clark AF, Nystuen A, Nichols BE, et al: Identification of a gene that causes primary open angle glaucoma. Science 275: 668-670, 1997.

65. Kumar S, Malik MA, Goswami S, Sihota R and Kaur J: Candidate genes involved in the susceptibility of primary open angle glaucoma. Gene 577: 119-131, 2016.

66. Sarfarazi M, Child A, Stoilova D, Brice G, Desai T, Trifan OC, Poinoosawmy D and Crick RP: Localization of the fourth locus (GLC1E) for adult-onset primary open-angle glaucoma to the 10p15-p14 region. Am J Hum Genet 62: 641-652, 1998.

67. Miyazawa A, Fuse N, Mengkegale M, Ryu M, Seimiya M, Wada Y and Nishida K: Association between primary open-angle glaucoma and WDR36 DNA sequence variants in Japanese. Mol Vis 13: 1912-1919, 2007.

68. Mookherjee S, Chakraborty S, Vishal M, Banerjee D, Sen A and Ray K: WDR36 variants in East Indian primary open-angle glaucoma patients. Mol Vis 17: 2618-2627, 2011

69. Jia LY, Tam PO, Chiang SW, Ding N, Chen LJ, Yam GH, Pang CP and Wang NL: Multiple gene polymorphisms analysis revealed a different profile of genetic polymorphisms of primary open-angle glaucoma in northern Chinese. Mol Vis 15: 89-98, 2009.

70. Pasutto F, Matsumoto T, Mardin CY, Sticht H, Brandstätter JH, Michels-Rautenstrauss K, Weisschuh N, Gramer E, Ramdas WD, van Koolwijk LM, et al: Heterozygous NTF4 mutations impairing neurotrophin-4 signaling in patients with primary open-angle glaucoma. Am J Hum Genet 85: 447-456, 2009.

71. Pasutto F, Keller KE, Weisschuh N, Sticht H, Samples JR Yang YF, Zenkel M, Schlötzer-Schrehardt U, Mardin CY, Frezzotti P, et al: Variants in ASB10 are associated with open-angle glaucoma. Hum Mol Genet 21: 1336-1349, 2012.

72. Fuse N: Genetic basies for glaucoma. Tohoku J Exp Med 221: $1-10,2010$

73. Gemenetzi M, Yang Y and Lotery AJ: Current concepts on primary open-angle glaucoma genetics: A contribution to disease pathophysiology and future treatment. Eye (Lond) 26: 355-369, 2012.

74. Allingham RR, Liu Y and Rhee DJ: The genetics of primary open-angle glaucoma: A review. Exp Eye Res 88: 837-844, 2009

75. Davis LK, MeyerKJ, SchindlerEI, BeckJS, RuddDS, Grundstad AJ, Scheetz TE, Braun TA, Fingert JH, Alward WL, et al: Copy number variations and primary open-angle glaucoma. Invest Ophthalmol Vis Sci 52: 7122-7133, 2011
76. Redon R, Ishikawa S, Fitch KR, Feuk L, Perry GH, Andrews TD, Fiegler H, Shapero MH, Carson AR, Chen W, et al: Global variation in copy number in the human genome. Nature 444: 444-454, 2006.

77. Rezaie T, Child A, Hitchings R, Brice G, Miller L, Coca-Prados M, Héon E, Krupin T, Ritch R, Kreutzer D, et al: Adult-onset primary open-angle glaucoma caused by mutations in optineurin. Science 295: 1077-1079, 2002.

78. Monemi S, Spaeth G, DaSilva A, Popinchalk S, Ilitchev E, Liebmann J, Ritch R, Héon E, Crick RP, Child A and Sarfarazi M: Identification of a novel adult-onset primary open-angle glaucoma (POAG) gene on 5q22.1. Hum Mol Genet 14: 725-733, 2005.

79. Rangachari K, Dhivya M, Eswari Pandaranayaka PJ, Prasanthi N, Sundaresan P, Krishnadas SR and Krishnaswamy S: Glaucoma database. Bioinformation 5: 398-399, 2011.

80. Fingert JH, Robin AL, Stone JL, Roos BR, Davis LK, Scheetz TE, Bennett SR, Wassink TH, Kwon YH, Alward WL, et al: Copy number variations on chromosome $12 \mathrm{q} 14$ in patients with normal tension glaucoma. Hum Mol Genet 20: 2482-2494, 2011

81. Porter LF, Urquhart JE, O'Donoghue E, Spencer AF, Wade EM, Manson FD and Black GC: Identification of a novel locus for autosomal dominant primary open angle glaucoma on 4q35.1-q35.2. Invest Ophthalmol Vis Sci 52: 7859-7865, 2011.

82. Ali M, McKibbin M, Booth A, Parry DA, Jain P, Riazuddin SA, Hejtmancik JF, Khan SN, Firasat S, Shires M, et al: Null mutations in LTBP2 cause primary congenital glaucoma. Am J Hum Genet 84: 664-671, 2009.

83. Kaur K, Mandal AK and Chakrabarti S: Primary congenital glaucoma and the involvement of CYP1B1. Middle East Afr J Ophthalmol 18: 7-16, 2011.

84. Fuchshofer R and Tamm ER: The role of TGF- $\beta$ in the pathogenesis of primary open-angle glaucoma. Cell Tissue Res 347: 279-290, 2012

85. Millá E, Hernan I, Gamundi MJ, Martínez-Gimeno M and Carballo M: Novel LMX1B mutation in familial nail-patella syndrome with variable expression of open angle glaucoma. Mol Vis 13: 639-648, 2007.

86. Vishal M, Sharma A,Kaurani L, Alfano G, Mookherjee S, Narta K, Agrawal J, Bhattacharya I, Roychoudhury S, Ray J, et al: Genetic association and stress mediated down-regulation in trabecular meshwork implicates MPP7 as a novel candidate gene in primary open angle glaucoma. BMC Med Genomics 9: 15, 2016.

87. Al-Dabbagh N, Al-Shahrani H, Al-Dohayan N, Mustafa M, Arfin $M$ and Al-AsmariAK: The SPARC-related modular calcium binding protein 2 (SMOC2) gene polymorphism in primary glaucoma: A case-control study. Clin Ophthalmol 11: 549-555, 2017.

88. Chakrabarti S, Kaur K, Rao KN, Mandal AK, Kaur I, Parikh RS and Thomas R: The transcription factor gene FOXC1 exhibits a limited role in primary congenital glaucoma. Invest Ophthalmol Vis Sci 50: 75-83, 2009

89. Moazzeni H, Akbari MT, Yazdani S and Elahi E: Expression of CXCL6 and BBS5 that may be glaucoma relevant genes is regulated by PITX2. Gene 593: 76-83, 2016.

90. Othman MI, Sullivan SA, Skuta GL, Cockrell DA, Stringham HM Downs CA, Fornés A, Mick A, Boehnke M, Vollrath D and Richards JE: Autosomal dominant nanophthalmos (NNO1)with high hyperopia and angle-closure glaucomamaps to chromosome 11. Am J Hum Genet 63: 1411-8, 1998.

91. Nongpiur ME, Khor CC, Jia H, Cornes BK, Chen LJ, Qiao C, Nair KS, Cheng CY, Xu L, George R, et al: ABCC5, a gene that influences the anterior chamber depth, is associated with primary angle closure glaucoma. PLoS Genet 10: e1004089, 2014.

92. Simpson A, Avdic A, Roos BR, DeLuca A, Miller K, Schnieders MJ, Scheetz TE, Alward WL and Fingert JH: LADD syndrome with glaucoma is caused by a novel gene. Mol Vis 23: 179-184, 2017.

93. Wu MY, Wu Y, Zhang Y, Liu CY, Deng CY, Peng L and Zhou L: Associations between matrix metalloproteinase gene polymorphisms and glaucoma susceptibility: A meta-analysis. BMC Ophthalmol 17: 48, 2017.

94. Micheal S, Saksens NTM, Hogewind BF, Khan MI, Hoyng CB and den Hollander AI: Identification of TP53BP2 as a novel candidate gene for primary open angle glaucoma by whole exome sequencing in a large multiplex family. Mol Neurobiol 55 $1387-1395,2018$

95. Liao RF, Zhong ZL, Ye MJ, Han LY, Ye DQ and Chen JJ: Identification of mutations in myocilin and beta-1,4-galactosyltransferase 3 genes in a Chinese family with primary open-angle glaucoma. Chin Med J (Engl) 129: 2810-2815, 2016. 
96. Vithana EN, Aung T, Khor CC, Cornes BK, Tay WT, Sim X, Lavanya R, Wu R, Zheng Y, Hibberd ML, et al: Collagen-related genes influence the glaucoma risk factor, central corneal thickness. Hum Mol Genet 20: 649-658, 2011.

97. Janssen SF, Gorgels TG, van der Spek PJ, Jansonius NM and Bergen AA: In silico analysis of the molecular machinery underlying aqueous humor production: Potential implications for glaucoma. J Clin Bioinforma 3: 21, 2013.

98. Tezel G: TNF-alpha signaling in glaucomatous neurodegeneration. Prog Brain Res 173: 409-421, 2008

99. Fujikawa K, Iwata T, Inoue K, Akahori M, Kadotani H, Fukaya M, Watanabe M, Chang Q, Barnett EM and Swat W: VAV2 and VAV3 as candidate disease genes for spontaneous glaucoma in mice and humans. PLoS One 5: e9050, 2010.

100. Cao D, Liu X, Guo X, Cong Y, Huang J and Mao Z: Investigation of the association between CALCRL polymorphisms and primary angle closure glaucoma. Mol Vis 15: 2202-2208, 2009.

101. Awadalla MS, Burdon KP, Thapa SS, Hewitt AW and Craig JE: A cross-ethnicity investigation of genes previously implicated in primary angle closure glaucoma. Mol Vis 18: 2247-2254, 2012.

102. Mabuchi F, Sakurada Y, Kashiwagi K, Yamagata Z, Iijima H and Tsukahara S: Association between genetic variants associated with vertical cup-to-disc ratio and phenotypic features of primary open-angle glaucoma. Ophthalmology 119: 1819-1825, 2012.

103. Junglas B, Kuespert S, Seleem AA, Struller T, Ullmann S, Bösl M, Bosserhoff A, Köstler J, Wagner R, Tamm ER and Fuchshofer R: Connective tissue growth factor causes glaucoma by modifying the actin cytoskeleton of the trabecular meshwork. Am J Pathol 180: 2386-2403, 2012.

104. Wang CY, Shen YC, Wei LC, Lin KH, Feng SC, Yang YY, Chiu CH and Tsai HY: Polymorphism in the TNF- $\alpha(-863)$ locus associated with reduced risk of primary open angle glaucoma. Mol Vis 18: 779-785, 2012.

105. Dursun O, Yilmaz A, Ayaz L and Tamer L: Serum levels and $\mathrm{H} / \mathrm{L}$ gene polymorphism of mannose-binding lectin in primary open angle glaucoma. Curr Eye Res 37: 212-217, 2012.

106. Kang JH, Wiggs JL, Haines J, Abdrabou W and Pasquale LR: Reproductive factors and NOS3 variant interactions in primary open-angle glaucoma. Mol Vis 17: 2544-2551, 2011.

107. Awadalla MS, Thapa SS, Burdon KP, Hewitt AW and Craig JE: The association of hepatocyte growth factor (HGF) gene with primary angle closure glaucoma in the Nepalese population. Mol Vis 17: 2248-2254, 2011.

108. Wittström E, Ponjavic V, Bondeson ML and Andréasson S: Anterior segment abnormalities and angle-closure glaucoma in a family with a mutation in the BEST1 gene and Best vitelliform macular dystrophy. Ophthalmic Genet 32: 217-227, 2011

109. Fernández-Martínez L, Letteboer S, Mardin CY, Weisschuh N, Gramer E, Weber BH, Rautenstrauss B, Ferreira PA, Kruse FE, Reis A, et al: Evidence for RPGRIP1 gene as risk factor for primary open angle glaucoma. Eur J Hum Genet 19: 445-451, 2011.

110. Mookherjee S, Banerjee D, Chakraborty S, Banerjee A, Mukhopadhyay I, Sen A and Ray K: Association of IL1A and IL1B loci with primary open angle glaucoma. BMC Med Genet 11: 99, 2010

111. Zhou T, Souzeau E, Sharma S, Siggs OM, Goldberg I, Healey PR, Graham S, Hewitt AW, Mackey DA, Casson RJ, et al: Rare variants in optic disc area gene CARD10 enriched in primary open-angle glaucoma. Mol Genet Genomic Med 4: 624-633, 2016

112. Âlvarez L, García M, González-Iglesias H, Escribano J, Rodríguez-Calvo PP, Fernández-Vega L and Coca-Prados M LOXL1 gene variants and their association with pseudoexfoliation glaucoma (XFG) in Spanish patients. BMC Med Genet 16 : 72,2015 .

113. Khawaja AP, Cooke Bailey JN, Kang JH, Allingham RR, Hauser MA, Brilliant M, Budenz DL, Christen WG, Fingert J, Gaasterland D, et al: Assessing the association of mitochondrial genetic variation with primary open-angle glaucoma using gene-set analyses. Invest Ophthalmol Vis Sci 57: 5046-5052, 2016.

114. Bailey JN, Loomis SJ, Kang JH, Allingham RR, Gharahkhani P, Khor CC, Burdon KP, Aschard H, Chasman DI, Igo RP Jr, et al: Genome-wide association analysis identifies TXNRD2, ATXN2 and FOXC1 as susceptibility loci for primary open-angle glaucoma. Nat Genet 48: 189-194, 2016.

115. Lascaratos G, Garway-Heath DF, Willoughby CE, Chau KY and Schapira AH: Mitochondrial dysfunction in glaucoma: Understanding genetic influences. Mitochondrion 12: 202-212, 2012 .
116. Liu Y, Bailey JC, Helwa I, Dismuke WM, Cai J, Drewry M, Brilliant MH, Budenz DL, Christen WG, Chasman DI, et al: A common variant in MIR182 is associated with primary open-angle glaucoma in the NEIGHBORHOOD consortium. Invest Ophthalmol Vis Sci 57: 3974-3981, 2016.

117. Chandra A, Abbas S, Raza ST, Singh L, Rizvi S and Mahdi F: Polymorphism of CYP46A1 and PPAR $\gamma 2$ genes in risk prediction of primary open angle glaucoma among North Indian population. Middle East Afr J Ophthalmol 23: 172-176, 2016

118. Shah MH, Tabanera N, Krishnadas SR, Pillai MR, Bovolenta P and Sundaresan P: Identification and characterization of variants and a novel 4 bp deletion in the regulatory region of SIX6, a risk factor for primary open-angle glaucoma. Mol Genet Genomic Med 5: 323-335, 2017.

119. Skowronska-Krawczyk D, Zhao L, Zhu J, Weinreb RN, Cao G, Luo J, Flagg K, Patel S, Wen C, Krupa M, et al: P16INK4a upregulation mediated by SIX6 defines retinal ganglion cell pathogenesis in glaucoma. Mol Cell 59: 931-940, 2015.

120. Shin HY, Park SW, Jung SH, Park HY, Jung KI, Chung YJ and Park CK: No evidence of association of heterozygous galactosylceramidase deletion with normal-tension glaucoma in a Korean population. J Glaucoma 25: e504-e506, 2016.

121. Nowak A, Majsterek I, Przybyłowska-Sygut K, Pytel D, Szymanek K, Szaflik J and Szaflik JP: Analysis of the expression and polymorphism of APOE, HSP, BDNF, and GRIN2B genes associated with the neurodegeneration process in the pathogenesis of primary open angle glaucoma. Biomed Res Int 2015: 258281, 2015.

122. Chen Y, Lin Y, Vithana EN, Jia L, Zuo X, Wong TY, Chen LJ, Zhu X, Tam PO, Gong B, et al: Common variants near ABCA1 and in PMM2 are associated with primary open-angle glaucoma. Nat Genet 46: 1115-1119, 2014.

123. Ayub H, Khan MI, Micheal S, Akhtar F, Ajmal M, Shafique S, Ali SH, den Hollander AI, Ahmed A, Qamar R, et al: Association of eNOS and HSP70 gene polymorphisms with glaucoma in Pakistani cohorts. Mol Vis 16: 18-25, 2010

124. Carbone MA, Chen Y, Hughes GA, Weinreb RN, Zabriskie NA, Zhang K and Anholt RR: Genes of the unfolded protein response pathway harbor risk alleles for primary open angle glaucoma. PLoS One 6: e20649, 2011

125. Ayub H, Micheal S, Akhtar F, Khan MI, Bashir S, Waheed NK, Ali M, Schoenmaker-Koller FE, Shafique S, Qamar R and Hollander AI: Association of a polymorphism in the BIRC6 gene with pseudoexfoliative glaucoma. PLoS One 9: e105023, 2014.

126. Chen Y, Chen X, Wang L, Hughes G, Qian S and Sun X: Extended association study of PLEKHA7 and COL11A1 with primary angle closure glaucoma in a Han Chinese population. Invest Ophthalmol Vis Sci 55: 3797-3802, 2014.

127. Cuchra M, Szaflik JP, Przybylowska-Sygut K, Gacek M, Kaminska A, Szaflik J and Majsterek I: The role of the 148 Asp/Glu polymorphism of the APE1 gene in the development and progression of primary open angle glaucoma development in the Polish population. Pol J Pathol 64: 296-302, 2013.

128. Surgucheva I and Surguchov A: Expression of caveolin in trabecular meshwork cells and its possible implication in pathogenesis of primary open angle glaucoma. Mol Vis 17: 2878-2888, 2011.

129. Thorleifsson G, Walters GB, Hewitt AW, Masson G, Helgason A, DeWan A, Sigurdsson A, Jonasdottir A, Gudjonsson SA, Magnusson KP, et al: Common variants near CAV1 and CAV2 are associated with primary open-angle glaucoma. Nat Genet 42 : 906-909, 2010.

130. Yu-Wai-Man P, Stewart JD, Hudson G, Andrews RM, Griffiths PG, Birch MK and Chinnery PF: OPA1 increases the risk of normal but not high tension glaucoma. J Med Genet 47: $120-125,2010$

131. Mossböck G, Weger M, Faschinger C, Schmut O and Renner W: Plasminogen activator inhibitor-1 4G/5G gene polymorphism and primary open-angle glaucoma. Mol Vis 14: 1240-1244, 2008.

132. Wang WH, McNatt LG, Pang IH, Hellberg PE, Fingert JH, McCartney MD and Clark AF: Increased expression of serum amyloid A in glaucoma and its effect on intraocular pressure. Invest Ophthalmol Vis Sci 49: 1916-1923, 2008.

133. Micheal S, Hogewind BF, Khan MI, Siddiqui SN, Zafar SN, Akhtar F, Qamar R, Hoyng CB and den Hollander AI: Variants in the PRPF8 gene are associated with glaucoma. Mol Neurobiol 55: 4504-4510, 2018. 
134. Woo SJ, Kim JY, Kim DM, Park SS, Ko HS and Yoo T: Investigation of the association between $677 \mathrm{C}>\mathrm{T}$ and $1298 \mathrm{~A}>\mathrm{C}$ 5,10 -methylenetetra-hydrofolate reductase gene polymorphisms and normal-tension glaucoma. Eye Lond 23: 17-24, 2009.

135. Clement CI, Goldberg I, Healey PR and Graham SL: Plasma homocysteine, MTHFR gene mutation, and open-angle glaucoma. J Glaucoma 18: 73-78, 2009.

136. Bhattacharya SK, Rockwood EJ, Smith SD, Bonilha VL, Crabb JS, Kuchtey RW, Robertson NG, Peachey NS, Morton CC and Crabb JW: Proteomics reveal Cochlin deposits associated with glaucomatous trabecular meshwork. J Biol Chem 280 6080-6084, 2005.

137. Bhattacharya SK, Crabb JS, Bonilha VL, Gu X, Takahara H and Crabb JW: Proteomics implicates peptidyl arginine deiminase 2 and optic nerve citrullination in glaucoma pathogenesis. Invest Ophthalmol Vis Sci 47: 2508-2514, 2006.

138. Vishal M, Sharma A, Kaurani L, Alfano G, Mookherjee S, Narta K, Agrawal J, Bhattacharya I, Roychoudhury S, Ray JB, et al: Genetic association and stress mediated down-regulation in trabecular meshwork implicates MPP7 as a novel candidate gene in primary open angle glaucoma. MC Med Genomics 9: 15, 2016.

139. Lu Y, Vitart V, Burdon KP, Khor CC, Bykhovskaya Y, Mirshahi A, Hewitt AW, Koehn D, Hysi PG, Ramdas WD, et al Genome-wide association analyses identify multiple loci associated with central corneal thickness and keratoconus. Nat Genet 45: 155-163, 2013.

140. Othman MI, Sullivan SA, Skuta GL, Cockrell DA, Stringham HM, Downs CA, Fornés A, Mick A, Boehnke M, Vollrath D and Richards JE: Autosomal dominant nanophthalmos (NNO1) with high hyperopia and angle-closure glaucoma maps to chromosome 11. Am J Hum Genet 63 : 1411-1418, 1998.

141. Schlötzer-Schrehardt U: New pathogenetic insights into pseudoexfoliation syndrome/glaucoma. Therapeutically relevant? Ophthalmologe 109: 944-951, 2012 (In German).

142. Fingert JH, Héon E, Liebmann JM, Yamamoto T, Craig JE, Rait J, Kawase K, Hoh ST, Buys YM, Dickinson J, et al: Analysis of myocilin mutations in 1703 glaucoma patients from five different populations. Hum Mol Genet 8: 899-905, 1999.

143. Sheffield VC, Stone EM, Alward WL, Drack AV, Johnson AT, Streb LM and Nichols BE: Genetic linkage of familial open angle glaucoma to chromosome 1q21-q31. Nat Genet 4: 47-50, 1993.

144. Rasnitsyn A, Doucette L, Seifi M, Footz T, Raymond V and Walter MA: FOXC1 modulates MYOC secretion through regulation of the exocytic proteins RAB3GAP1, RAB3GAP2 and SNAP25. PLoS One 12: e0178518, 2017.

145. Kubota R, Kudoh J, Mashima Y, Asakawa S, Minoshima S, Hejtmancik JF, Oguchi Y and Shimizu N: Genomic organization of the human myocilin gene (MYOC) responsible for primary open angle glaucoma (GLC1A). Biochem Biophys Res Commun 242: 396-400, 1998

146. Michels-Rautenstrauss KG, Mardin CY, Budde WM, Liehr T, Polansky J, Nguyen T, Timmerman V, Van Broeckhoven C, Naumann GO, Pfeiffer RA and Rautenstrauss BW: Juvenile open angle glaucoma: Fine mapping of the TIGR gene to 1q24.3-q25.2 and mutation analysis. Hum Genet 102: 103-106, 1998.

147. Nguyen TD, Chen P, Huang WD, Chen H, Johnson D and Polansky JR: Gene structure and properties of TIGR, an olfactomedin-related glycoprotein cloned from glucocorticoid-induced trabecular meshwork cells. J Biol Chem 273: 6341-6350, 1998

148. Johnson DH: Myocilin and glaucoma: A TIGR by the tail? Arch Ophthalmol 118: 974-978, 2000.

149. Karali A, Russell P, Stefani FH and Tamm ER: Localization of myocilin/trabecular meshwork-inducible glucocorticoid response protein in the human eye. Invest Ophthalmol Vis Sci 41: 729-740, 2000.

150. Abu-Amero KK, Azad TA, Spaeth GL, Myers J, Katz LJ, Moster M and Bosley TM: Unaltered myocilin expression in the blood of primary open angle glaucoma patients. Mol Vis 18: 1004-1009, 2012.

151. Jacobson N, Andrews M, Shepard AR, Nishimura D, Searby C, Fingert JH, Hageman G, Mullins R, Davidson BL, Kwon YH, et al: Non-secretion of mutant proteins of the glaucoma gene myocilin in cultured trabecular meshwork cells and in aqueous humor. Hum Mol Genet 10: 117-125, 2001.
152. Joe MK, Sohn S, Hur W, Moon Y, Choi YR and Kee C: Accumulation of mutant myocilins in ER leads to ER stress and potential cytotoxicity in human trabecular meshwork cells. Biochem Biophys Res Commun 312: 592-600, 2003.

153. Gobeil S, Rodrigue MA, Moisan S, Nguyen TD, Polansky JR, Morissette $\mathrm{J}$ and Raymond V: Intracellular sequestration of hetero-oligomers formed by wild-type and glaucoma-causing myocilin mutants. Invest Ophthalmol Vis Sci 45: 3560-3567, 2004.

154. Liu Y and Vollrath D: Reversal of mutant myocilin non-secretion and cell killing: Implications for glaucoma. Hum Mol Genet 13: 1193-1204, 2004.

155. Kwon YH, Fingert JH, Kuehn MH and Alward WL: Primary open-angle glaucoma. N Engl J Med 360: 1113-1124, 2009.

156. Tamm ER: The functional role of myocilin in glaucoma ophthalmology research: Mechanisms of the glaucomas. Humana Press: Totowa: 219-231, 2009.

157. Carbone MA, Ayroles JF, Yamamoto A, Morozova TV, West SA, Magwire MM, Mackay TF and Anholt RR: Overexpression of myocilin in the Drosophila eye activates the unfolded protein response: Implications for glaucoma. PLoS One 4: e4216, 2009.

158. Moreno JA, Halliday M, Molloy C, Radford H, Verity N, Axten JM, Ortori CA, Willis AE, Fischer PM, Barrett DA and Mallucci GR: Oral treatment targeting the unfolded protein response prevents neurodegeneration and clinical disease in prion-infected mice. Sci Transl Med 5: 206ra138, 2013.

159. Wentz-Hunter K, Ueda J, Shimizu N and Yue BY: Myocilin is associated with mitochondria in human trabecular meshwork cells. J Cell Physiol 190: 46-53, 2002.

160. Wentz-Hunter K, Shen X and Yue BY: Distribution of myocilin, a glaucoma gene product, in human corneal fibroblasts. Mol Vis 9: $308-314,2003$

161. He Y, Leung KW, Zhuo YH and Ge J: Pro370Leu mutant myocilin impairs mitochondrial functions in human trabecular meshwork cells. Mol Vis 15: 815-825, 2009.

162. Kumar A, Basavaraj MG, Gupta SK, Qamar I, Ali AM, Bajaj V, Ramesh TK, Prakash DR, Shetty JS and Dorairaj SK: Role of CYP1B1, MYOC, OPTN, and OPTC genes in adult-onset primary open-angle glaucoma: predominance of CYP1B1 mutations in Indian patients. Mol Vis 13: 667-676, 2007.

163. Fan BJ, Wang DY, Fan DS, Tam PO, Lam DS, Tham CC, Lam CY, Lau TC and Pang CP: SNPs and interaction analyses of myocilin, optineurin, and apolipoprotein $\mathrm{E}$ in primary open angle glaucoma patients. Mol Vis 11: 625-631, 2005.

164. Forsman E, Lemmelä S, Varilo T, Kristo P, Forsius H, Sankila EM and Järvelä I: The role of TIGR and OPTN in Finnish glaucoma families: A clinical and molecular genetic study. Mol Vis 9: 217-222, 2003.

165. Rakhmanov VV, Nikitina NIa, Zakharova FM, Astakhov IuS Kvasova MD, Vasil'ev VB, Golubkov VI and Mandel'shtam MIu: Mutations and polymorphisms in the genes for myocilin and optineur in as the risk factors of primary open-angle glaucoma. Genetika 41: 1567-1574, 2005 (In Russian).

166. Yao HY, Cheng CY, Fan BJ, Tam OS, Tham CY, Wang DY, Lam SC and Pang CP: Polymorphisms of myocilin and optineurin in primary open angle glaucoma patients. Zhonghua Yi Xue Za Zhi 86: 554-559, 2006 (In Chinese).

167. Park BC, Tibudan M, Samaraweera M, Shen X and Yue BY: Interaction between two glaucoma genes, optineurin and myocilin. Genes Cells 12: 969-979, 2007.

168. Vincent AL, Billingsley G, Buys Y, Levin AV, Priston M, Trope G, Williams-Lyn D and Héon E: Digenic inheritance of early-onset glaucoma: CYP1B1, a potential modifier gene. Am J Hum Genet 70: 448-460, 2002.

169. Kaur K, Reddy AB, Mukhopadhyay A, Mandal AK, Hasnain SE, Ray K, Thomas R, Balasubramanian D and Chakrabarti S: Myocilin gene implicated in primary congenital glaucoma. Clin Genet 67: 335-340, 2005

170. Cai SP, Muhemaiti P, Yin Y, Cheng H, Di Ya A, Keyimu M, Cao X, Fan N, Jiang L, Yan N, et al: A novel MYOC heterozygous mutation identified in a Chinese Uygur pedigree with primary open-angle glaucoma. Mol Vis 18: 1944-1951, 2012.

171. Tanwar M, Kumar M, Dada T, Sihota R and Dada R: MYOC and $\mathrm{FOXC1}$ gene analysis in primary congenital glaucoma. $\mathrm{Mol}$ Vis 16: 1996-2006, 2010.

172. Sirohi K and Swarup G: Defects in autophagy caused by glaucoma-associated mutations in optineurin. Exp Eye Res 144: 54-63, 2016. 
173. Lopez-Martinez F, Lopez-Garrido MP, Sanchez-Sanchez F, Campos-Mollo E, Coca-Prados M and Escribano J: Role of MYOC and OPTN sequence variations in Spanish patients with primary open-angle glaucoma. Mol Vis 13: 862-872, 2007.

174. Funayama T, Ishikawa K, Ohtake Y, Tanino T, Kurasaka D, Kimura I, Suzuki K, Ideta H, Nakamoto K, Yasuda N, et al: Variants in optineurin gene and their association with tumor necrosis factor-alpha polymorphisms in Japanese patients with glaucoma. Invest Ophthal Vis Sci 45: 4359-4367, 2004

175. Nagabhushana A, Chalasani ML, Jain N, Radha V, Rangaraj N, Balasubramanian D and Swarup G: Regulation of endocytic trafficking of transferrin receptor by optineurin and its impairment by a glaucoma-associated mutant. BMC Cell Biol 11: 4, 2010

176. Sripriya S, Nirmaladevi J, George R, Hemamalini A, Baskaran M, Prema R, Ve Ramesh S, Karthiyayini T, Amali J, Job S, et al: OPTN gene: Profile of patients with glaucoma from India. Mol Vis 12: 816-820, 2006.

177. Mukhopadhyay A, Komatireddy S, Acharya M, Bhattacharjee A, Mandal AK, Thakur SK, Chandrasekhar G, Banerjee A, Thomas R, Chakrabarti S and Ray K: Evaluation of Optineurin as a candidate gene in Indian patients with primary open angle glaucoma. Mol Vis 11: 792-797, 2005.

178. Footz TK, Johnson JL, Dubois S, Boivin N, Raymond V and Walter MA: Glaucoma-associated WDR36 variants encode functional defects in a yeast model system. Hum Mol Genet 18: 1276-1287, 2009.

179. Fingert JH, Alward WL, Kwon YH, Shankar SP, Andorf JL, Mackey DA, Sheffield VC and Stone EM: No association between variations in the WDR36 gene and primary open-angle glaucoma. Arch Ophthalmol 125: 434-436, 2007.

180. Liu Y, Liu W, Crooks K, Schmidt S, Allingham RR and Hauser MA: No evidence of association of heterozygous NTF4 mutations in patients with primary open-angle glaucoma. Am J Hum Genet 86: 498-499, 2010.

181. Chen LJ, Ng TK, Fan AH, Leung DY, Zhang M, Wang N, Zheng Y, Liang XY, Chiang SW, Tam PO, et al: Evaluation of NTF4 as a causative gene for primary open-angle glaucoma. Mol Vis 18: 1763-1772, 2012.

182. Vithana EN, Nongpiur ME, Venkataraman D, Chan SH, Mavinahalli J and Aung T: Identification of a novel mutation in the NTF4 gene that causes primary open-angle glaucoma in a Chinese population. Mol Vis 16: 1640-1645, 2010.

183. Murakami K, Meguro A, Ota M, Shiota T, Nomura N, Kashiwagi K, Mabuchi F, Iijima H, Kawase K, Yamamoto T, et al: Analysis of microsatellite polymorphisms within the GLC1F locus in Japanese patients with normal tension glaucoma. Mol Vis 16: 462-466, 2010.

184. Keller KE, Yang YF, Sun YY, Sykes R, Acott TS and Wirtz MK: Ankyrin repeat and suppressor of cytokine signaling box containing protein-10 is associated with ubiquitin-mediated degradation pathways in trabecular meshwork cells. Mol Vis 19 1639-1655, 2013.

185. Mackay DS, Bennett TM and Shiels A: Exome sequencing identifies a missense variant in EFEMP1 co-segregating in a family with autosomal dominant primary open-angle glaucoma. PLoS One 10: e0132529, 2015.

186. Springelkamp H, Mishra A, Hysi PG, Gharahkhani P, Höhn R, Khor CC, Cooke Bailey JN, Luo X, Ramdas WD, Vithana E, et al: Meta-analysis of genome-wide association studies identifies novel loci associated with optic disc morphology. Genet Epidemiol 39: 207-216, 2015.

187. Junglas B, Kuespert S, Seleem AA, Struller T, Ullmann S, Bösl M, Bosserhoff A, Köstler J, Wagner R, Tamm ER and Fuchshofer R: Connective tissue growth factor causes glaucoma by modifying the actin cytoskeleton of the trabecular meshwork. Am J Pathol 180: 2386-2403, 2012.

188. Fuchshofer R, Stephan DA, Russell P and Tamm ER: Gene expression profiling of TGFbeta2- and/or BMP7-treated trabecular meshwork cells: Identification of Smad7 as a critical inhibitor of TGF-beta2 signaling. Exp Eye Res 88: 1020-1032, 2009.

189. Keller KE, Yang YF, Sun YY, Sykes R, Gaudette ND, Samples JR, Acott TS and Wirtz MK: Interleukin-20 receptor expression in the trabecular meshwork and its implication in glaucoma. J Ocul Pharmacol Ther 30: 267-276, 2014.

190. Wirtz MK and Keller KE: The role of the IL-20 subfamily in glaucoma. Mediators Inflamm 2016: 4083735, 2016.

191. Howell GR, Walton DO, King BL, Libby RT and John SW: Datgan, a reusable software system for facile interrogation and visualization of complex transcription profiling data. BMC Genomics 12: 429, 2011
192. Narooie-Nejad M, Paylakhi SH, Shojaee S, Fazlali Z, Rezaei Kanavi M, Nilforushan N, Yazdani S, Babrzadeh F, Suri F, Ronaghi M, et al: Loss of function mutations in the gene encoding latent transforming growth factor beta binding protein 2, LTBP2, cause primary congenital glaucoma. Hum Mol Genet 18: 3969-3977, 2009.

193. Sarfarazi M: Recent advances in molecular genetics of glaucomas. Hum Mol Genet 6: 1667-1677, 1997.

194. Choudhary D, Jansson I, Rezaul K, Han DK, Sarfarazi M and Schenkman JB: Cyplb1 protein in the mouse eye during development: An immunohistochemical study. Drug Metab Dispos 35: 987-994, 2007.

195. Li N, Zhou Y, Du L, Wei M and Chen X: Overview of cytochrome P450 1B1 gene mutations in patients with primary congenital glaucoma. Exp Eye Res 93: 572-579, 2011.

196. Plásilová M, Stoilov I, Sarfarazi M, Kádasi L, Feráková E and Ferák V: Identification of a single ancestral CYP1B1 mutation in Slovak Gypsies (Roms) affected with primary congenital glaucoma. J Med Genet 36: 290-294, 1999

197. Do T, Shei W, Chau PT, Trang DL, Yong VH, Ng XY, Chen YM, Aung T and Vithana EN: CYP1B1 and MYOC mutations in vietnamese primary congenital glaucoma patients. J Glaucoma 25: e491-e498, 2016.

198. Hogewind BF, Gaplovska-Kysela K, Theelen T, Cremers FP, Yam GH, Hoyng CB and Mukhopadhyay A: Identification and functional characterization of a novel MYOC mutation in two primary open angle glaucoma families from The Netherlands. Mol Vis 13: 1793-1801, 2007.

199. Patel HY, Richards AJ, De Karolyi B, Best SJ, Danesh-Meyer HV and Vincent AL: Screening glaucoma genes in adult glaucoma suggests a multiallelic contribution of CYP1B1 to open-angle glaucoma phenotypes. Clin Exp Ophthalmol 40: e208-e217, 2012.

200.López-Garrido MP, Sánchez-Sánchez F, López-Martínez F, Aroca-Aguilar JD, Blanco-Marchite C, Coca-Prados M and Escribano J: Heterozygous CYP1B1 gene mutations in Spanish patients with primary open-angle glaucoma. Mol Vis 12 : 748-755, 2006

201. Acharya M, Mookherjee S, Bhattacharjee A,Bandyopadhyay AK, Daulat Thakur SK, Bhaduri G, Sen A and Ray K: Primary role of CYP1B1 in Indian juvenile-onset POAG patients. Mol Vis 12: 399-404, 2006.

202.Zenteno JC, Hernandez-Merino E, Mejia-Lopez H, Matías-Florentino M, Michel N, Elizondo-Olascoaga C, Korder-Ortega V, Casab-Rueda $\mathrm{H}$ and Garcia-Ortiz JE: Contribution of CYP1B1 mutations and founder effect to primary congenital glaucoma in Mexico. J Glaucoma 17: $189-192,2008$

203. Faiq MA, Dada R, Qadri R and Dada T: CYP1B1-mediated pathobiology of primary congenital glaucoma. J Curr Glaucoma Pract 9: 77-80, 2015

204. Sarfarazi M and Stoilov I: Molecular genetics of primary congenital glaucoma. Eye Lond 14: 422-428, 2000.

205. Kakiuchi-Matsumoto T, Isashiki Y, Ohba N, Kimura K, Sonoda S and Unoki K: Cytochrome P450 1B1 gene mutations in Japanese patients with primary congenital glaucoma(1). Am J Ophthalmol 131: 345-350, 2001.

206. Kabra M, Zhang W, Rathi S, Mandal AK, Senthil S, Pyatla G, Ramappa M, Banerjee S, Shekhar K, Marmamula S, et al: Angiopoietin receptor TEK interacts with CYP1B1 in primary congenital glaucoma. Hum Genet 136: 941-949, 2017.

207. Mohanty K, Tanwar M, Dada R and Dada T: Screening of the LTBP2 gene in a north Indian population with primary congenital glaucoma. Mol Vis 19: 78-84, 2013

208. Safari I, Akbarian S, Yazdani S and Elahi E: A possible role for LTBP2 in the etiology of primary angle closure glaucoma. J Ophthalmic Vis Res 10: 123-129, 2015.

209. Chen X, Chen Y, Fan BJ, Xia M, Wang L and Sun X: Screening of the LTBP2 gene in 214 Chinese sporadic CYP1B1-negative patients with primary congenital glaucoma. Mol Vis 22: $528-535,2016$

210. Souma T, Tompson SW, Thomson BR, Siggs OM, Kizhatil K, Yamaguchi S, Feng L, Limviphuvadh V, Whisenhunt KN, Maurer-Stroh S, et al: Angiopoietin receptor TEK mutations underlie primary congenital glaucoma with variable expressivity. J Clin Invest 126: 2575-2587, 2016.

211. Kizhatil K, Ryan M, Marchant JK, Henrich S and John SW: Schlemm's canal is a unique vessel with a combination of blood vascular and lymphatic phenotypes that forms by a novel developmental process. PLoS Biol 12: e1001912, 2014. 
212. Kasetti RB, Phan TN, Millar JC and Zode GS: Expression of mutant myocilin induces abnormal intracellular accumulation of selected extracellular matrix proteins in the trabecular meshwork. Invest Ophthalmol Vis Sci 57: 6058-6069, 2016.

213. Williams AL, Eason J, Chawla B and Bohnsack BL: Cyp1b1 regulates ocular fissure closure through a retinoic acid-independent pathway. Invest Ophthalmol Vis Sci 58: 1084-1097, 2017.

214. García-Antón MT, Salazar JJ, de Hoz R, Rojas B, Ramírez AI, Triviño A, Aroca-Aguilar JD, García-Feijoo J, Escribano J and Ramírez JM: Goniodysgenesis variability and activity of CYP1B1 genotypes in primary congenital glaucoma. PLoS One 12: e0176386, 2017.

215. Reis LM, Tyler RC, Weh E, Hendee KE, Kariminejad A, Abdul-Rahman O, Ben-Omran T, Manning MA, Yesilyurt A, McCarty CA, et al: Analysis of CYP1B1 in pediatric and adult glaucoma and other ocular phenotypes. Mol Vis 22: 1229-1238, 2016.

216. Jain A,Zode G, Kasetti RB, Ran FA, Yan W, Sharma TP,Bugge K, Searby CC, Fingert JH, Zhang F, et al: CRISPR-Cas9-based treatment of myocilin-associated glaucoma. Proc Natl Acad Sci USA 114: 11199-11204, 2017.
217. Daliri K, Ljubimov AV and Hekmatimoghaddam S: Glaucoma, stem cells, and gene therapy: Where are we now? Int J Stem Cells 10: 119-128, 2017.

218. Shah SZA, Zhao D, Hussain T and Yang L: The role of unfolded protein response and mitogen-activated protein kinase signaling in neurodegenerative diseases with special focus on prion diseases. Front Aging Neurosci 9: 120, 2017.

219. Chong WC, Shastri MD and Eri R: Endoplasmic reticulum stress and oxidative stress: A vicious nexus implicated in bowel disease pathophysiology. Int J Mol Sci 18: pii: E771, 2017.

220. Lindholm D, Korhonen L, Eriksson O and Kõks S: Recent insights into the role of unfolded protein response in er stress in health and disease. Front Cell Dev Biol 5: 48, 2017.

221. Jackrel ME and Shorter J: Protein-remodeling factors as potential therapeutics for neurodegenerative disease. Front Neurosci 11: 99, 2017. International (CC BY-NC-ND 4.0) License. 